\title{
Japan: 2010 Article IV Consultation-Staff Report; Public Information Notice on the Executive Board Discussion
}

Under Article IV of the IMF's Articles of Agreement, the IMF holds bilateral discussions with members, usually every year. In the context of the 2010 Article IV consultation with Japan, the following documents have been released and are included in this package:

- $\quad$ The staff report for the 2010 Article IV consultation, prepared by a staff team of the IMF, following discussions that ended on May 19, 2010, with the officials of Japan on economic developments and policies. Based on information available at the time of these discussions, the staff report was completed on June 17, 2010. The views expressed in the staff report are those of the staff team and do not necessarily reflect the views of the Executive Board of the IMF.

- $\quad$ A Public Information Notice (PIN) summarizing the views of the Executive Board as expressed during its July 2, 2010 discussion of the staff report that concluded the Article IV consultation.

The document listed below has been or will be separately released.

\section{Selected Issues Paper}

The policy of publication of staff reports and other documents allows for the deletion of market-sensitive information.

\author{
Copies of this report are available to the public from \\ International Monetary Fund • Publication Services \\ $70019^{\text {th }}$ Street, N.W. • Washington, D.C. 20431 \\ Telephone: (202) 623-7430 • Telefax: (202) 623-7201 \\ E-mail: publications@imf.org Internet: http://www.imf.org
}

\section{International Monetary Fund Washington, D.C.}




\section{INTERNATIONAL MONETARY FUND}

\section{JAPAN \\ Staff Report for the 2010 Article IV Consultation}

Prepared by the Staff Representatives for the 2010 Consultation with Japan

Approved by James Gordon and Tamim Bayoumi

June 17, 2010

- This report is based on discussions held in Tokyo during May 10-19. The team comprised Mr. Gordon (Head), Ms. Kochhar, Messrs. Kang, Danninger, Syed, and Tokuoka, Ms. Berkmen (all APD), and Mr. Steinberg (OAP). Mr. Lipsky joined the mission for the policy discussions and to chair a seminar co-hosted by OAP and the Ministry of Finance on reshaping the global financial landscape and the implications for Asia. Messrs. Kotegawa and Yamaoka (both OED) participated in the policy discussions.

- Counterparts. The mission met with Bank of Japan (BoJ) Governor Shirakawa, Senior Vice Minister of Finance Noda, Senior Vice Minister of the Cabinet Office Furukawa, Senior Vice Minister of the Cabinet Office Ohtsuka, Vice Minister of Finance for International Affairs Tamaki, BoJ Deputy Governors Nishimura and Yamaguchi, and other senior officials, academics, and private sector representatives.

- Context of past surveillance. In its last consultation, Fund staff and the authorities agreed on the need for fiscal consolidation with adjustment to begin once the crisis abates. Staff also supported the BoJ's accommodative monetary policy stance and recommended strengthening the resilience of the banking sector to a protracted slowdown. There was a consensus that growth needed to be rebalanced towards stronger domestic demand.

- Selected Issues Papers assess the impact of fiscal consolidation and structural reforms on growth in Japan and explore policy options to raise medium-term growth (investment and household spending).

- Japan's exchange rate is market determined. Japan has accepted the obligations of Article VIII. The exchange system is free of restrictions on the making of current international transactions, with the exceptions of those notified to the Fund in accordance with Executive Board Decision 144-(52/51) and UN-sanctioned restrictions on external payments for security reasons. 


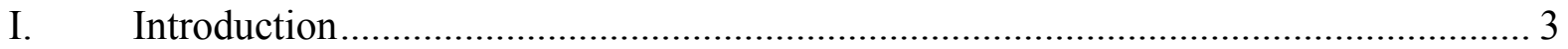

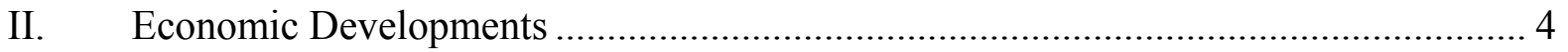

III. Economic Outlook and Risks....................................................................... 7

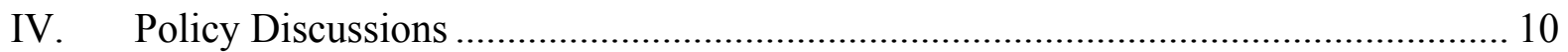

A. Mapping A Credible Fiscal Reform Strategy ................................................. 10

B. Monetary Policy Options to Combat Deflation................................................. 16

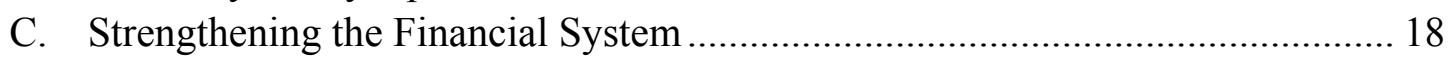

D. Reforms to Raise Medium-Term Growth .......................................................... 22

V. Exchange Rate, External Stability, and Spillovers .............................................. 24

VI. Staff Appraisal ................................................................................................ 25

Boxes

1. Potential Impact of Global Sovereign Debt Strains on Japan ..................................

2. Estimating the Growth Impact of Fiscal Adjustment ............................................13

3. Exploring Supply-Side Reforms to Raise Growth..................................................23

Tables

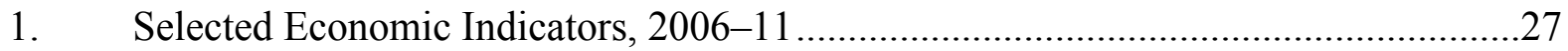

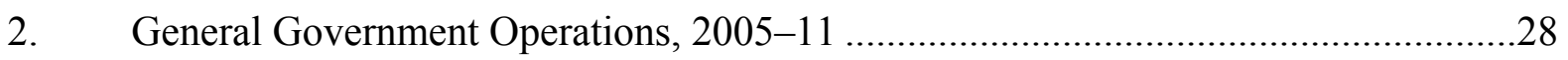

3. External and Financial Indicators, 2005-11 ..........................................................29

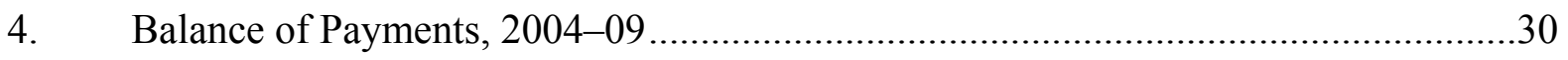

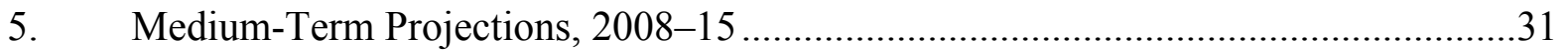

Appendices

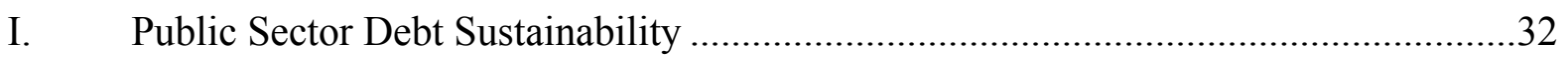




\section{EXECUTIVE SUMMARY}

Context: Japan's economy continues to improve led by robust exports and policy stimulus while deflation pressures appear to be easing. The recent turmoil in Europe has raised the uncertainty and downside risks around the outlook and sharpened the focus on Japan's high public debt ratio, which is one of the highest among advanced economies. Bringing down the debt ratio will require a large and protracted adjustment that will be made more credible by an early increase in the consumption tax. Further easing measures by the Bank of Japan would support the recovery and help combat deflation.

\section{Policy messages:}

- The cyclical upswing offers an opportunity to embark on critical reforms. Fiscal adjustment should start in FY2011 (starting April 2011) beginning with a modest consumption tax hike.

- To put the public net debt ratio firmly on a downward path, the authorities should aim for a 1 percent of GDP annual reduction in the structural primary deficit over ten years. Achieving this goal will require a combination of additional tax rate increases, expenditure containment, and entitlement reform.

- A fiscal rule capping the level of public debt and targeting a primary surplus would strengthen credibility and help lock-in fiscal gains.

- Further easing measures by the Bank of Japan (BoJ) could help support the recovery and reduce deflation pressures.

- Supervisors should ensure that banks properly manage risks from a slower recovery and heightened market volatility and take appropriate steps to strengthen their capital position.

- To raise potential growth and support fiscal consolidation, structural reforms should aim to raise labor participation, improve access to financing for innovative firms, and increase productivity in new growth sectors (e.g., health care and environment).

\section{INTRODUCTION}

1. Japan's economy is gaining strength, but vulnerability to sovereign risk is rising. Sizeable policy support and strong external demand, especially from Asia, are driving the recovery, but large fiscal deficits driven by fiscal stimulus and the recession have pushed public debt to unprecedented levels. With global scrutiny of public finances on the rise, the need for early and credible fiscal adjustment has increased. At the same time, deflation has re-emerged, while the financial system faces a number of challenges including from renewed financial market turmoil and changes in global financial regulations.

\section{The new government has signaled a greater willingness to consider needed fiscal}

reforms. In response to growing concerns over Japan's public debt, Prime Minister Kan has voiced support for greater fiscal discipline and an early debate on the consumption taxissues which will likely feature in the government's medium-term growth and fiscal strategies due at end-June. The future direction of reforms, however, will likely depend on 
the outcome of July Upper House elections with possible ramifications for the government's policy priorities.

\section{ECONOMIC DEVELOPMENTS}

\section{Japan's export-led recovery continued to strengthen through the first quarter} of 2010. Following a deep recession - GDP declined 5.2 percent in 2009-growth accelerated to 5 percent (s.a.a.r.) in the first quarter of 2010 amid signs of exports spilling over to domestic demand.

- $\quad$ Exports. Japan's real exports have rebounded after falling by almost 40 percent $(y / y)$ at the trough of the crisis. Strong demand from Asia, especially for capital goods, has supported the recovery, pushing export growth to 30 percent s.a.a.r. in Q1 2010. The rebound, however, has lagged that of other advanced economies due to the yen's appreciation and a shift in demand away from higher-value added products in which Japan specializes.

- Consumption. Despite a sharp fall in disposable household income, private consumption contributed positively to growth in 2009. Spending was supported mainly by fiscal stimulus, especially subsidies on "green" durable goods that accounted for much of the spending growth.

- $\quad$ Labor market. The labor market is gradually recovering. The unemployment rate declined from its peak in mid-2009 to 5.1 percent in April 2010, while the ratio of job offers-to-seekers has begun rising from depressed levels. Total earnings grew for the first time in March (1 percent $y / y)$ after having fallen continuously since the Lehman shock.
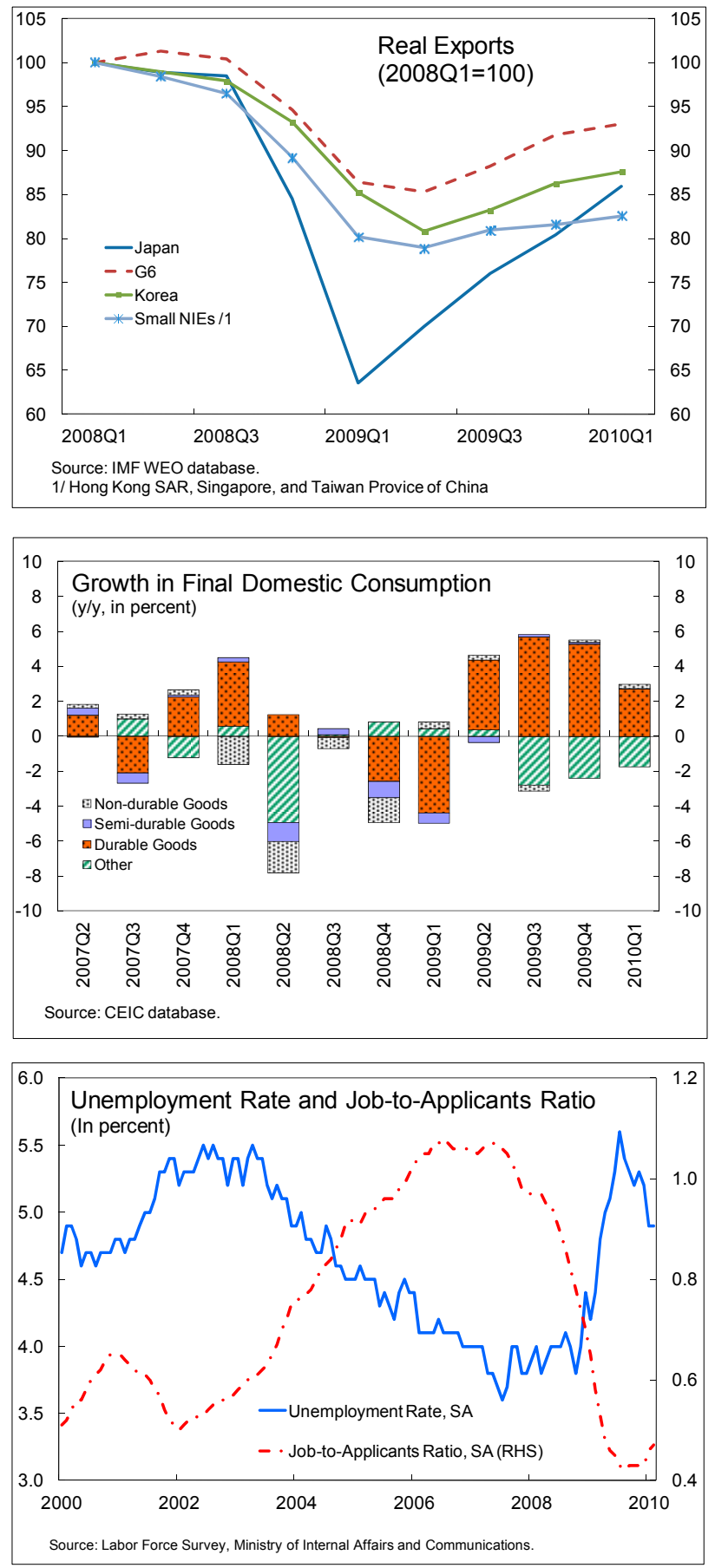


\section{Deflation has re-emerged, mainly reflecting the large output gap as well as} structural factors. Since the onset of the Lehman crisis, consumer prices have steadily declined as a result of an unwinding of the commodity price boom and falling demand.

- $\quad$ Structural factors. Japan has a long history of persistent low-grade inflation. Headline CPI inflation turned negative as early as 1995 while core inflation has hovered around $-1 / 2$ percent for most of the decade. This reflects not only a series of large shocks (including the 1980s asset bubble burst and banking crisis), but also structural factors such as deregulation in product and labor markets, lower

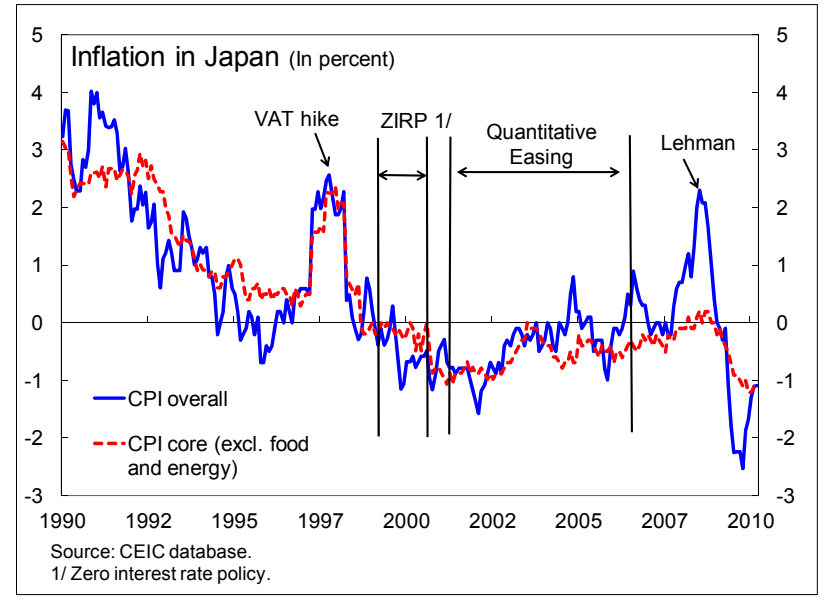
trend growth from population aging, and competitive pressures from China.

- $\quad$ Output gap. Since the onset of the global crisis, core inflation in Japan has fallen by more than in other advanced economies. A significant part of the decline can be attributed to Japan's deeper recession and larger output gap (estimated at around 6 percent of GDP at end2009). With the recovery gaining strength, core inflation has stabilized at around -1.1 percent since late 2009. ${ }^{1}$

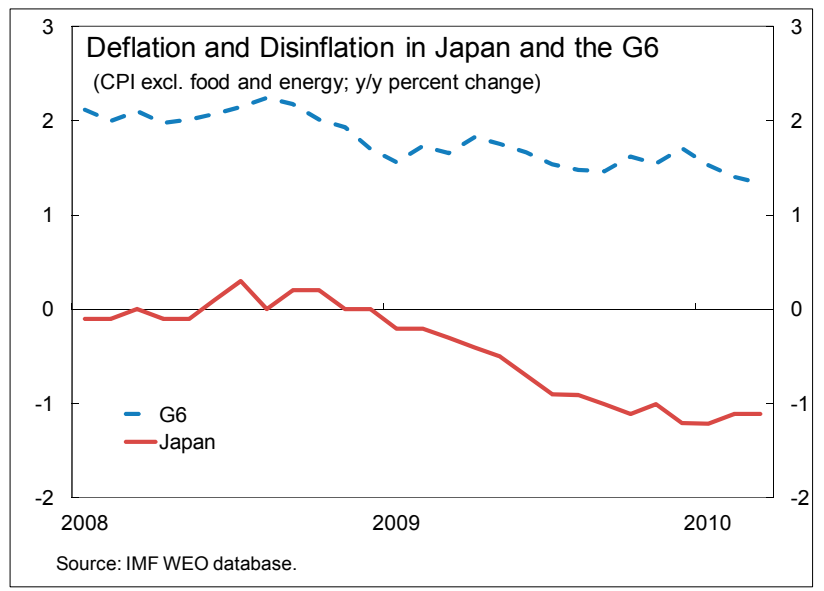

5. Financial markets have been hit hard by the renewed global turmoil. After showing signs of recovering through March of 2010, equity prices have fallen and the yen again appreciated on Europe-related fears, but the fallout on money and credit markets has so far been limited.

\footnotetext{
${ }^{1}$ Core inflation (excluding fresh food) fell to -1.5 percent (y/y) in April 2010 as a result of a one-off administrative price change related to the introduction of high school tuition waivers which staff estimated to have lowered the CPI by $1 / 2$ percentage point. The impact of the price change is expected to disappear after one year.
} 
- $\quad$ Financial conditions. Financial conditions continued to improve in 2009, but remain tighter than preLehman reflecting the yen's real appreciation and falling equity prices. Since end of March 2009, the Nikkei index has rebounded by around 20 percent (as of end of May 2010), but the rally has lagged that in the rest of the region and elsewhere, partly reflecting weakness in bank shares.

- $\quad$ Money markets. The 3-month LIBOR-OIS spread, an indicator of counterparty risk, has gradually narrowed to pre-Lehman levels. The BoJ's liquidity operations have helped to stabilize short-term money markets, but term spreads beyond 3 months still remain elevated.
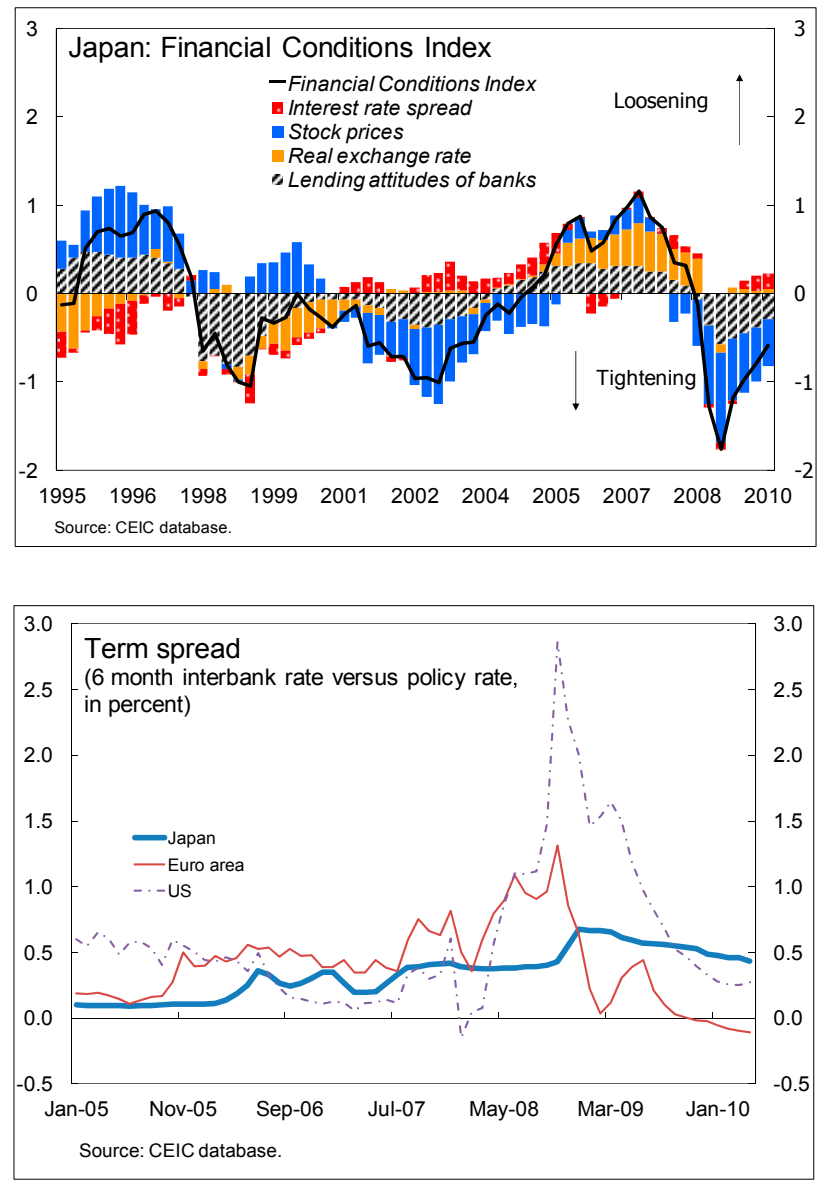

- $\quad$ Sovereign debt markets. Despite higher public debt and larger deficits, 10-year Japanese government bond (JGB) yields have been stable at around 1.2-

1.4 percent, supported by ample demand domestically and safe haven flows. The market has also been aided by rising corporate savings, which have been channeled into JGBs through the banking system.

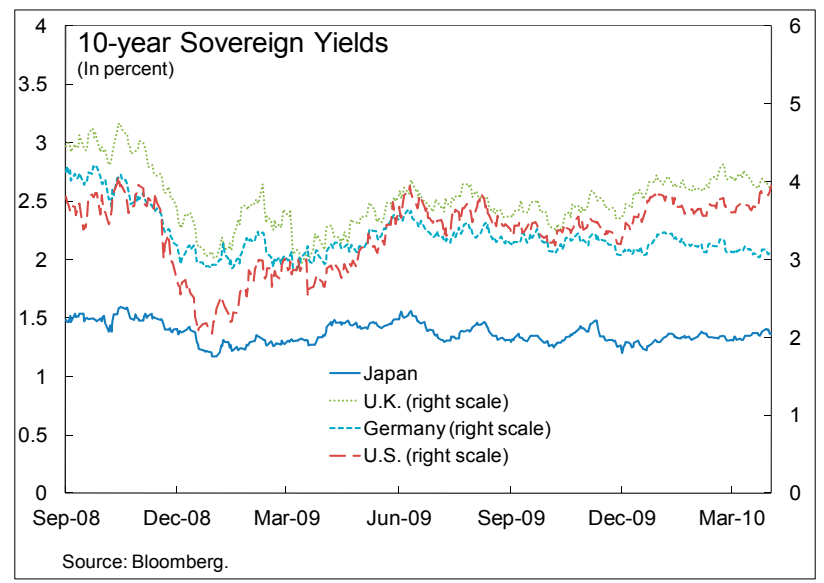


6. The current account surplus has fallen, but the recovery in external demand has stemmed the decline.

- $\quad$ Current account. The current account surplus shrank further in 2009, as a result of lower global interest rates and a stronger yen. Although export volumes recovered along with world demand, the recovery was not as pronounced as in other countries. As a result, the trade surplus remained roughly unchanged at around 1 percent of GDP, while the income balance deteriorated in line with low global interest rates.

- $\quad$ Exchange rate. Since the Lehman shock, the yen has appreciated by 16 percent in real effective terms (down from close to 25 percent in early 2009), reflecting an unwinding of yen carry-trades and a flight to safety, most recently from Europe-related concerns.
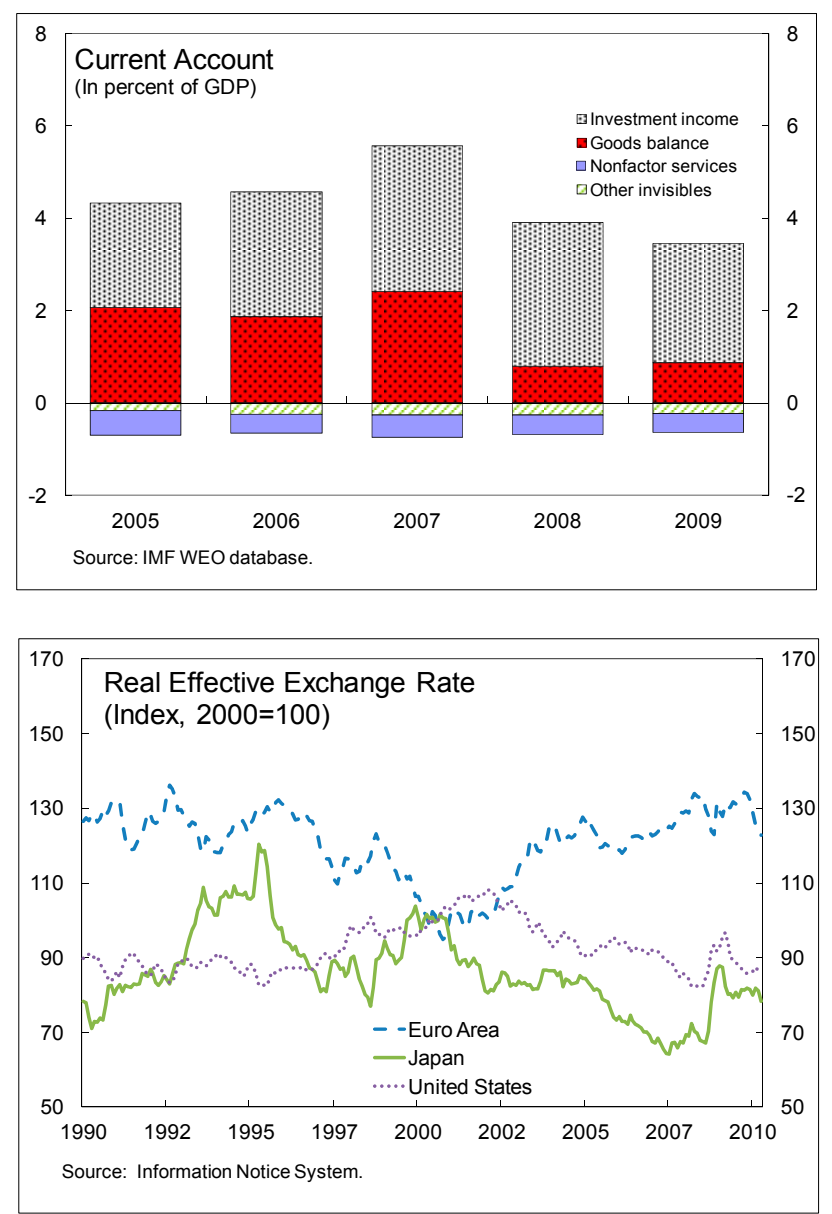

\section{ECONOMIC OUTLOOK AND RISKS}

\section{The recovery is expected to} continue but its pace will likely

moderate. GDP growth is projected to rise to 2.4 percent in 2010 with the pace of the recovery likely to moderate in the second half of the year as stimulus measures expire and export growth levels off. Growth of 1.8 percent is expected in 2011 . With a narrowing of the output gap, headline inflation is projected to turn positive in late 2011. Supported by a resumption of

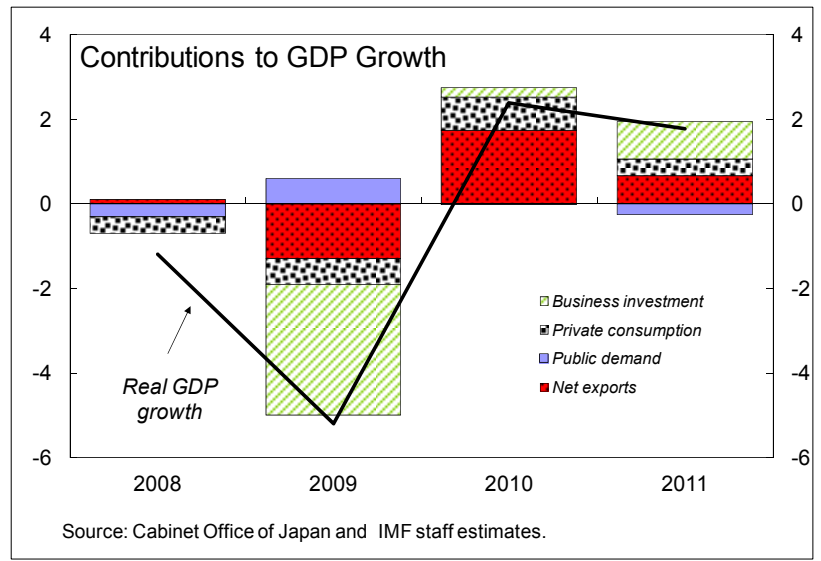
investment, potential growth is projected to increase from around $1 / 2$ to 1 percent over the medium term. 


\section{Considerable uncertainty}

surrounds the outlook. Sustained yen appreciation could dampen external demand, while sovereign risk pressures may force governments around the world to scale back their spending. Similarly, a slowdown in China would weaken import demand from the region and Japan.

Domestic risks to growth stem primarily from a worsening of deflation, which could

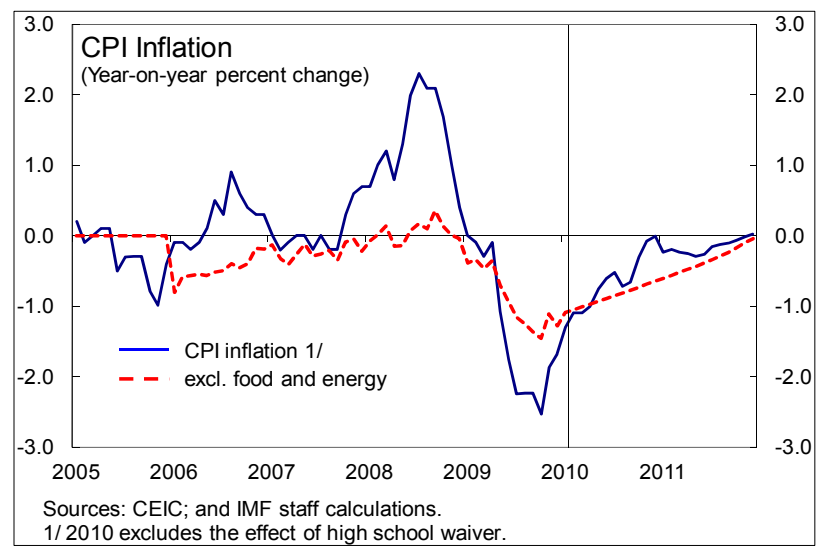
depress investment and consumption. On the upside, more robust growth in the United States and emerging economies would sustain higher export growth.

\section{Recent events in Europe have increased the chances of a tail risk event (Box 1).}

A loss of market confidence in sovereign debt could lead to a sudden rise in risk premia worldwide and push up long-term interest rates in Japan. Under such a scenario, growth would slow sharply, further prolonging deflation, and undermining the fiscal position. A sharp slowdown would also spill over to the rest of the region through reduced trade and capital flows.

\section{The Authorities' Views}

10. The authorities broadly agreed with staff's assessment of the outlook and risks.

- Near-term outlook. Officials noted that the outlook had improved in recent months on the back of robust exports and encouraging signs of strengthening domestic demand. This view was shared by the BoJ's Policy Board, which raised its growth forecast in the April semi-annual Economic Outlook for Economic Activity and Prices to 1.8 percent in FY2010 and 2.0 percent in FY2011. With concerns over deflation diminishing with the strong recovery, the BoJ forecasts core inflation (excluding fresh food) to turn positive in FY2011, in line with staff's projections.

- $\quad$ Risks. The authorities noted that the uncertainty around the economic outlook had increased in light of the renewed financial turmoil. In addition, they expressed concern about rising asset price inflation and a possible hard landing in China, which is a significantly larger export market than Europe (19 vs. 12 percent of exports in 2009). 


\section{Box 1. Potential Impact of Global Sovereign Distress on Japan.}

To assess the impact of sovereign distress on growth, two downside tail-risk scenarios were explored using the IMF's Global Integrated Monetary and Fiscal (GIMF) model.

1. Sovereign debt crisis and increased risk premium. Assessing the macroeconomic implications of a sharp rise in government bond yields, this scenario assumes an increase in the risk premium by 100 basis points for the U.S. and 200 basis points for the euro area without offsetting fiscal policy. If the risk premium in Japan remains unaffected, growth would slow through the export and exchange rate channel by between 0.5 to 1 percentage points in 2010. If, on the other hand, the risk premium in Japan also increases (by 100 basis points), growth could fall by as much as 2 percentage points. Given depressed demand, deflation would worsen by about 0.5 to 1 percentage point below the baseline in 2011 .

2. Double dip in the advanced economies.

A second scenario models the effects of a sharp growth slowdown in the U.S. and euro area on Japan. The scenario assumes a confidence driven decline in both consumption and investment in the U.S. and the euro area pushing growth in both areas below zero in 2010. As a result, real export growth in Japan could slow by 4 5 percentage points, with negative spillovers to investment and consumption. Japan's GDP growth

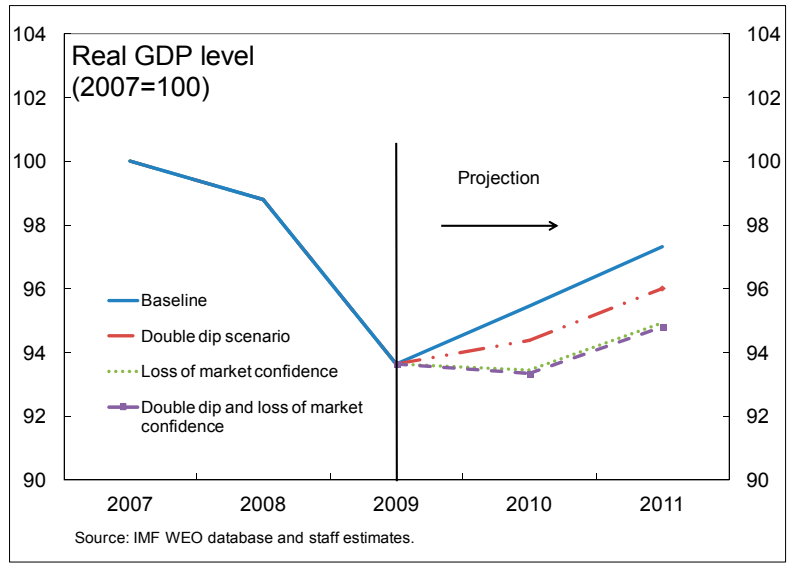
would be about 1 percentage point lower relative to the baseline and remain subdued in 2011. Deflation would worsen by about 0.5 percentage point.

Both tail risk scenarios can potentially occur together significantly affecting exports and growth prospects. The two scenarios, however, have opposite exchange rate effects. Some of the appreciation pressures created by a flight to quality in the second scenario would be offset by a depreciation from a loss in trade in the first scenario. Overall, the negative impact on the growth rate could be as large as $2-3$ percentage points, with deflation remaining below the baseline by about 1 percentage point in 2011. If accompanied by an independent growth slowdown in China (e.g. by 5 percent) growth in Japan could be dampened by a further $1 / 2-1$ percentage point given the importance of Asia as an export destination (about 50 percent of overall exports).

In the event that inflation expectations become unanchored and deflation self propagates, a forceful policy response may be needed. With interest rates already at the zero bound, unconventional measures may be needed, such as full-scale quantitative easing, to stimulate activity and anchor inflation expectations. In contrast, fiscal policy has limited room to respond and adjustment would need to proceed, although possibly at a more moderate pace. However, if the slowdown was linked to a rise in the sovereign risk premium, fiscal consolidation may need to accelerate to restore confidence in public finances. 


\section{Policy Discussions}

Japan's recovery continues, but vulnerability to sovereign risk has risen. Timely and decisive policy action and strong external demand are driving the recovery, but large fiscal deficits have pushed public debt to even higher levels. With global scrutiny of public finances increasing, the need for policy action to rein in the large fiscal deficit has risen. Such efforts would be helped by additional measures to combat deflation and policies to spur growth while safeguarding financial stability. Against this backdrop, this year's Article IV consultation focused on policies to achieve lasting fiscal adjustment, measures to support the recovery and combat deflation, and reforms to raise medium-term growth.

\section{A. Mapping A Credible Fiscal Reform Strategy}

\section{Background}

\section{Decisive government action has helped to support the recovery. Fiscal} stimulus in Japan is sizeable, estimated at around $2 \frac{1}{2}$ percent of GDP in both 2009 and 2010. Measures have focused on employment support and subsidies for energy efficient products. Starting in June 2010, the government will also provide child allowances, which if fully implemented would amount to $3 / 4$ percent of GDP annually (excluding existing allowances).

\section{The severe recession and the fiscal response have pushed debt to unprecedented} levels.

- Fiscal developments. The overall fiscal deficit is estimated to have widened to $10 \frac{1}{4}$ percent of GDP in 2009 compared to $2 \frac{1}{2}$ percent of GDP in 2007, reflecting lower nominal GDP, fiscal stimulus, and a sharp drop in corporate revenue. The deficit is projected to narrow moderately to $93 / 4$ percent of GDP in 2010, with a modest reduction in stimulus and a gradual recovery in

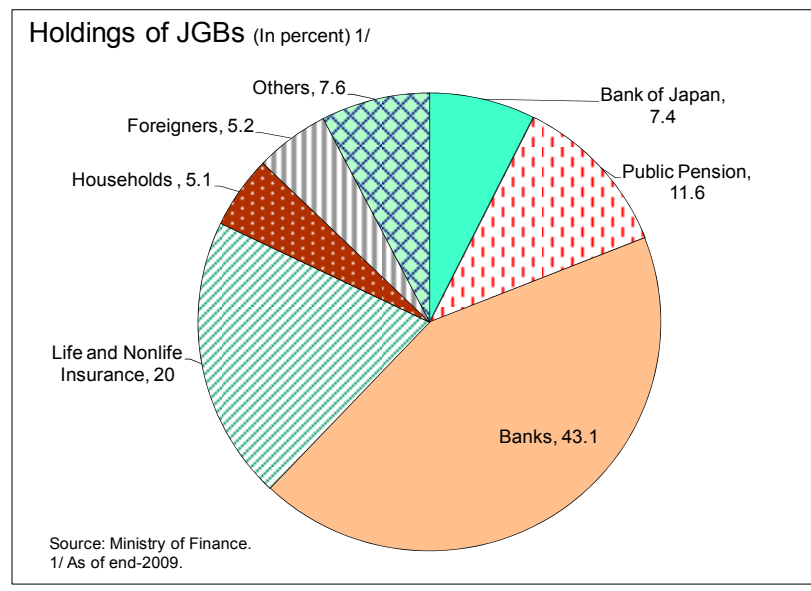
revenue. 
- Debt position. Net public debt rose sharply from 80 percent of GDP in 2007 to 110 percent of GDP at end-2009 (215 percent in gross terms), one of the highest among advanced economies.

- Fiscal risks. Although the near-term funding risks are lowered by the large share of public debt held domestically (95 percent), sizeable household savings, and a current account surplus, the capacity of the market to absorb JGBs will gradually diminish as population aging reduces saving. ${ }^{2}$

\section{The authorities are planning to release their medium-term fiscal strategy by}

end-June. A strategy for reducing Japan's public debt will need to take into account Japan's comparatively low expenditure ratio and a low revenue share from indirect taxes.

- $\quad$ Expenditure. The scope for further spending cuts is limited. General government expenditure including social security was 33 percent of GDP in 2007, the lowest among G-7 economies. Since the early 2000 s, non-social security expenditures have been flat, but social security related spending has risen and will continue to do so with an aging population.

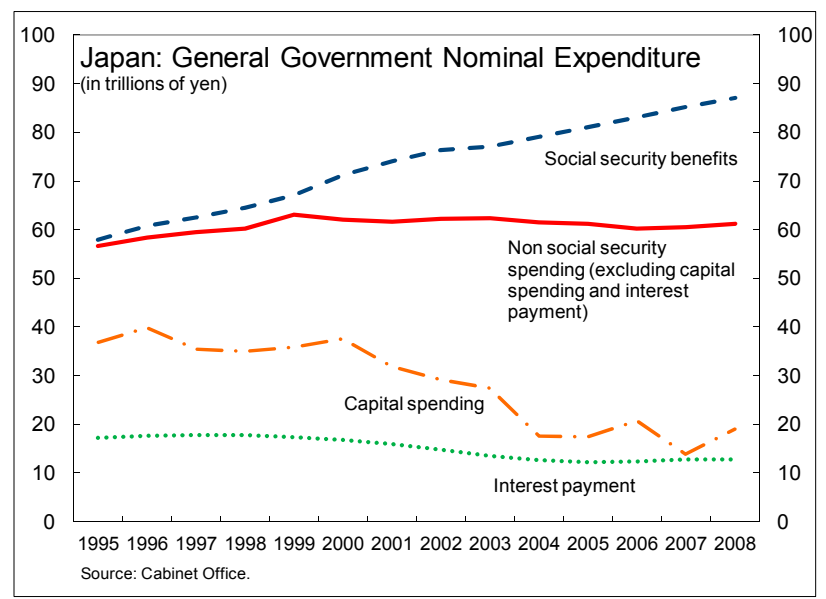

- $\quad$ Tax revenue. Japan's overall tax revenue is small by international standards at 18 percent of GDP in 2007, partly due to the low consumption tax rate at 5 percent. In addition, the personal income tax system features large deductions that serve to reduce average tax rates. By contrast, the corporate tax rate (40 percent) is comparatively high.

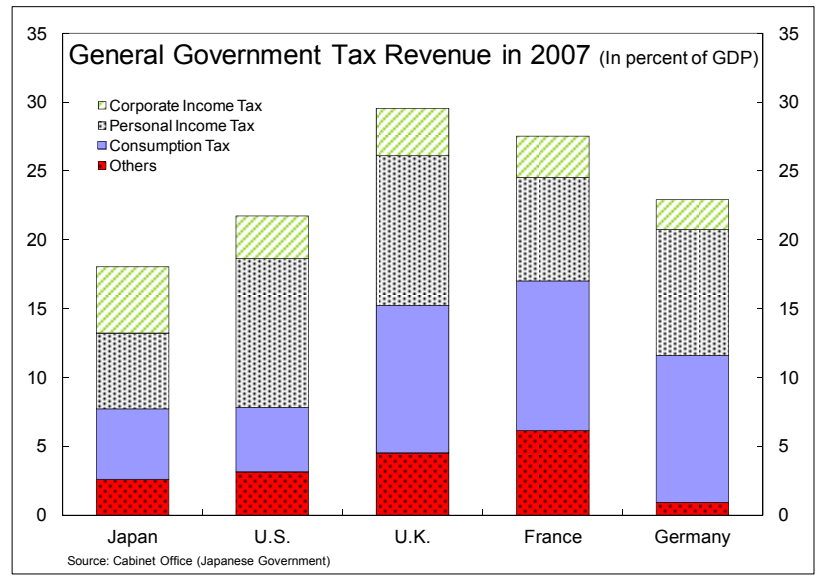

\footnotetext{
${ }^{2}$ Tokuoka, K. (2009) “The Outlook for Financing Japan’s Public Debt,” IMF Working Paper No. 10/19.
} 


\section{Policy Issues and Staff Views}

14. Fiscal adjustment should begin in FY2011 to capitalize on the cyclical recovery and be sustained for at least a decade. Staff analysis suggests that stabilizing the net debtto-GDP ratio at 140 percent of GDP (240 percent in gross terms) in 2014 and placing it firmly on a downward path would require a reduction of the structural primary deficit by about 1 percent per year for the next 10 years (see Appendix I). This adjustment path would strike a balance between reversing the debt dynamics in a decisive manner (benefiting medium-term growth prospects) and safeguarding the recovery given Japan's low current trend growth (estimated at 1 percent). Announcing an upfront increase in the consumption tax would strengthen credibility of the adjustment plan and boost confidence in the long-term viability of the social security system.

15. Adjustment could be achieved in a number of ways centered around an increase in the consumption tax rate (see table). Given the limited scope for cutting expenditures, fiscal adjustment will need to rely mainly on new revenue sources and limits on spending growth. In addition to letting fiscal stimulus expire (savings of 1-2 percent of GDP), the main elements of a credible package could include:

- $\quad$ Comprehensive tax reform. A gradual increase of the consumption tax to 15 percent beginning in FY2011 and distributed over several years, could generate 4-5 percent of GDP of revenue. This measure could be combined with a reduction of personal income tax allowances and corporate tax reform to stimulate domestic investment. The progress made in introducing a single number system for taxpayers and social security should help in strengthening collections.

- $\quad$ Limiting expenditure growth. Containing public spending growth and reforming pension entitlements in line with rising life expectancy could generate additional savings of around 3-4 percent of GDP over the next decade. Measures could include freezing non-social security spending in nominal terms; limiting fast-rising health-care costs and other social entitlements; introducing an income cap on social transfers; and raising the statutory retirement age (currently at 65 years).

16. Fiscal adjustment may dampen activity in the near term, but would raise growth over time (Box 2). Based on GIMF model simulations, staff estimates that relative to its baseline, the fiscal reform program would slow growth by about $1 / 3$ percentage point per year on average over the first 3-5 years. Thereafter, GDP would expand at a faster rate than in the baseline as public debt declines and gains in confidence boost investment and consumption. If accompanied by reforms to boost productivity, longer-term growth benefits could be larger. 


\section{Box 2. Estimating the Growth Impact of Fiscal Adjustment ${ }^{1}$}

Simulations based on the IMF's GIMF model were used to assess the possible growth impact of a 1 percent of GDP per year fiscal adjustment over the next decade. The scenario assumes a phased-in increase of the consumption tax (raising revenues by 5 percent of GDP) and a decline in corporate income tax (reducing revenues by $1 / 2$ percent of GDP). In addition, the scenario assumes a decline in government consumption by 2 percent of the GDP and in public investment by $1 / 2$ percent of GDP. The rest of the adjustment comes from transfers. The simulations also assume some frontloading of adjustment with more than half of the adjustment taking place within the first 3 years, mainly as a result of higher consumption taxes.

In the short-term, fiscal adjustment could depress growth by as little as 0.3-0.5 percentage points per year. The negative impact stems from a reduction in domestic demand as a result of a gradual increase in consumption taxes, lower government consumption, and declining public investment. The demand effect is magnified by the limited scope for monetary policy at the zero interest rate bound, but could be partly offset by the positive investment response from a

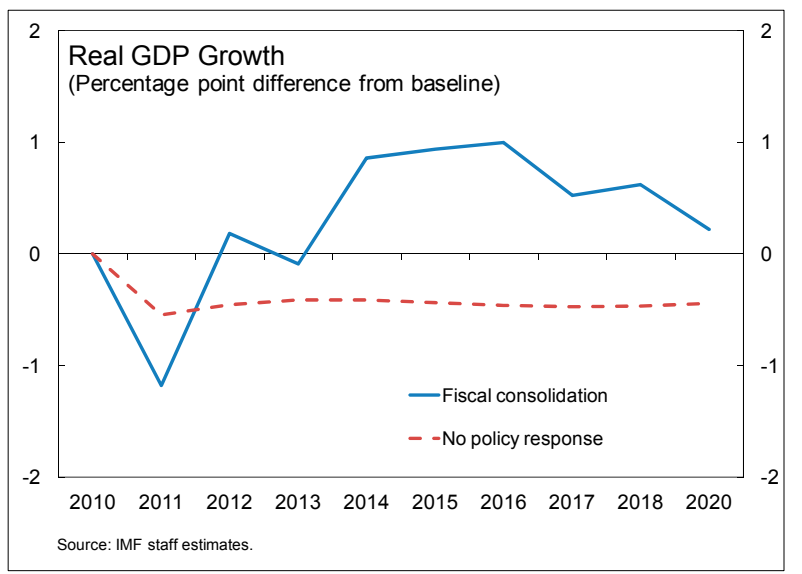
reduction in corporate taxes.

However, in the medium term, assuming accrued benefits from improved consumer and investor confidence, growth could rise above the baseline by about $1 / 2$ percent per year. In addition to higher investment from lower corporate taxes, the main growth benefits from fiscal consolidation are:

- Reduction in precautionary savings. Part of the decline in consumption due to higher consumption taxes would be offset by a reduction in precautionary savings. In particular, younger generations appear concerned about fiscal sustainability and the pension system and are potentially saving more now than otherwise.

- Reduction of the risk premium. Japan is likely to pay a risk premium on its debt over the long term in the absence of fiscal consolidation. Such an increase in risk premium would increase the cost of capital, depressing investment and growth.

- Confidence effects. A credible fiscal consolidation could also improve business confidence and encourage investment.

As these benefits are likely to materialize gradually, the negative demand effects will dominate in the short term. Fiscal adjustment will also raise national savings compared to the baseline, pulling up the medium-term current account balance. In contrast, real GDP could be depressed significantly if no policy action is taken, with risk premium increasing gradually over time and potential GDP declining as investment prospects worsen.

${ }^{1}$ See Selected Issues Paper on "Fiscal Consolidation and Structural Reforms Implications for Japan." 
17. Fiscal adjustment would be aided by the adoption of a fiscal rule. An explicit long-term fiscal rule would strengthen the commitment to cap public debt and anchor expectations of sustainable fiscal policy. Such a framework was recently adopted in Germany and has generally been effective in constraining debt growth in Switzerland ("debt brake"). ${ }^{3}$ In Japan, a new fiscal framework could target a primary fiscal balance consistent with a debt limit and be based on prudent economic assumptions and narrowly defined escape clauses.

\section{Given the large and growing public debt stock, effective debt management}

remains critical. The authorities have gradually raised the average maturity of outstanding public debt (including short-term financing bills) to an estimated 5-5 1/2 years. Nonetheless, gross public financing needs for maturing and new debt is large partly due to a sizeable increase in short-term financing bills. ${ }^{4}$ Adopting an asset-liability management approach covering both JGBs and financing bills could strengthen public debt management and the monitoring of maturity risk.

\begin{tabular}{|c|c|c|c|c|c|c|}
\hline \multicolumn{7}{|c|}{$\begin{array}{l}\text { Potential Options for Gradual Fiscal Adjustment Over Next } 10 \text { Years }{ }^{1 /} \\
\text { (In percent of GDP) }\end{array}$} \\
\hline \multirow[b]{2}{*}{$\begin{array}{l}\text { Consumption Tax Rate }{ }^{2 /} \\
\text { (In percent, currently at } 5 \text { pct) }\end{array}$} & & \multicolumn{5}{|c|}{ Option } \\
\hline & & 14 & 15 & 17 & 18 & 22 \\
\hline \multirow[t]{2}{*}{$\begin{array}{l}\text { Revenue from consumption } \\
\text { tax hike }\end{array}$} & & 4.5 & 5.0 & 6.0 & 6.5 & 8.5 \\
\hline & $\begin{array}{l}\text { Assumed } \mathrm{i} \\
\text { over } 10 \mathrm{y}\end{array}$ & \multirow[b]{2}{*}{$\checkmark$} & \multirow[b]{2}{*}{$\checkmark$} & \multirow[b]{2}{*}{$\boldsymbol{\nu}$} & \multirow[b]{2}{*}{$\boldsymbol{v}$} & \multirow[b]{2}{*}{$\checkmark$} \\
\hline Withdrawal of fiscal stimulus & 1.5 & & & & & \\
\hline $\begin{array}{l}\text { Freeze non social security spending } \\
\text { (excluding interest payment) in nominal } \\
\text { terms }\end{array}$ & 2.5 & $\boldsymbol{v}$ & $\boldsymbol{v}$ & $\boldsymbol{v}$ & $\checkmark$ & \\
\hline $\begin{array}{l}\text { Hold nominal growth in non pension } \\
\text { social security spending at } 1-1.5 \text { percent } \\
\text { (annually) }\end{array}$ & 1.0 & $\checkmark$ & $\checkmark$ & & & \\
\hline $\begin{array}{l}\text { Freeze national contributions to the } \\
\text { public pension in nominal terms, } \\
\text { including through raising eligible age }\end{array}$ & 0.5 & $\checkmark$ & $\boldsymbol{v}$ & & & \\
\hline Corporate tax cut & -0.5 & & $\boldsymbol{v}$ & & $\boldsymbol{v}$ & \\
\hline \multicolumn{2}{|l|}{ Total savings $3 /$} & 10.0 & 10.0 & 10.0 & 10.0 & 10.0 \\
\hline \multicolumn{7}{|c|}{$\begin{array}{l}1 / \text { Nominal GDP growth is assumed to be around } 2 \text { percent per year over the next } 10 \text { years, while the (nominal) interest } \\
\text { rate growth differential is assumed to converge to } 1 \frac{11 / 4}{4} \text { percent (pre-crisis average since } 2000 \text { ) over the long term. } \\
2 / \text { To be adjusted gradually over a } 10 \text {-year period. }\end{array}$} \\
\hline \multicolumn{7}{|c|}{$\begin{array}{l}\text { 3/ With this adjustment, the net debt-GDP ratio (general government basis) would peak at around } 140 \text { percent in } 2014 \\
\text { ( } 240 \text { percent of GDP in gross terms) and steadily decline afterwards. }\end{array}$} \\
\hline
\end{tabular}

\footnotetext{
${ }^{3}$ Switzerland's debt brake rule from 2003 sets a one-year ahead ceiling on government expenditures and mandates that any cyclical overruns be offset by adjustments in future budgets.

${ }^{4}$ In FY2010, financing needs amount to around 30 percent of GDP for JGBs and 20 percent of GDP for shortterm financing bills.
} 


\section{The Authorities' Views and Policy Intentions}

\section{The authorities are determined to tackle fiscal consolidation to maintain public confidence.}

- $\quad$ Timing and composition. While the authorities shared the view that fiscal consolidation was needed, they stressed that given downside risks, including from external developments and deflation, the timing and pace of the adjustment should be decided prudently. That said, they agreed that current events in Europe provided greater urgency to embark on reforms. In this regard, options were being explored to limit JGB issuances in FY2011 to the current level. The authorities shared the staff's conclusion that revenue measures focused on raising the consumption tax would be necessary to close the fiscal gap. They observed that a higher consumption tax would have the additional advantage of reducing the cyclical volatility of the tax base. They also indicated that discussions were ongoing about a possible reduction in the corporate income tax rate.

- $\quad$ Growth effects. The authorities concurred that credible fiscal consolidation could have positive confidence effects in the near term, potentially overcoming the negative demand effects from fiscal consolidation. They also noted that raising trend growth through their soon-to-be-released growth strategy would support adjustment.

- $\quad$ Fiscal strategy. As part of a possible fiscal rule, the authorities are considering a "pay-as you-go" requirement (where new expenditures would be funded by offsetting spending cuts or additional revenue) and introducing a multi-year expenditure framework to strengthen budget discipline and planning. The authorities stressed that any medium-term adjustment plans would need to be based on prudent macroeconomic assumptions and include sufficient flexibility to avoid the fiscal strategy being derailed by unexpected swings in growth. Because of synergies between fiscal and structural reforms, the authorities were exploring the possibility of comprehensive reform legislation linking fiscal consolidation to growth enhancing measures and social security reforms.

- $\quad$ Debt management. Given the large domestic investor base, the authorities saw little near-term financing risk. They indicated that demand for long-term debt was robust, particularly among life insurance companies, and that they would continue lengthening maturities of JGBs to reduce roll-over risks. The authorities stressed that in assessing fiscal risks, short-term financing bills should be treated separately from JGBs since the former are primarily used for cash management and are backed by the government's foreign exchange reserve holdings. 


\section{B. Monetary Policy Options to Combat Deflation}

\section{Background}

20. To combat the recession and re-emergence of deflation, the BoJ adopted a number of additional measures:

- $\quad$ Reducing term premia. In December 2009, the BoJ introduced a 3-month funds supplying facility to lower short-term interest rates that was doubled in size in March 2010 to 20 trillion yen. The introduction of the new facility was followed by a modest decline of the 3-month interest rate and coincided with a leveling off of the inflation rate. In December 2009, the BoJ also unwound its commercial paper and corporate bond purchasing program in response to improved market conditions.

- $\quad$ Communications. In December 2009, the BoJ clarified its understanding of medium to long-term price stability to correspond to an inflation rate in "a positive range of 2 percent or lower" (previously "in the range approximately between 0 and 2 percent"). The BoJ also reiterated that an inflation rate of 1 percent was the midpoint of most Policy Board members' understanding of price stability.

- Loan facility. To "strengthen the foundations for economic growth", the BoJ announced in April 2010 the introduction of a new facility that would supply funds at a very low interest rate to private banks to finance lending to innovative firms.

- $\quad$ Dollar swap agreement. In response to financial market strains in Europe and to preempt any emerging dollar funding pressures, the BoJ re-activated in May 2010 its dollar swap agreement with the U.S. Federal Reserve and re-established its U.S. dollar funds supplying operations.

\section{Policy Issues and Staff views}

21. While deflation pressures are easing, a slow recovery carries risk that deflation could become more entrenched. A stalled recovery or sharp yen appreciation could push prices down further and unhinge inflation expectations which have declined in the past year. According to survey data, the share of the public that expects prices to fall or remain unchanged over the next five years has almost doubled to 30 percent since early 2007. If deflation expectations spread and growth slows again, the risk could rise that

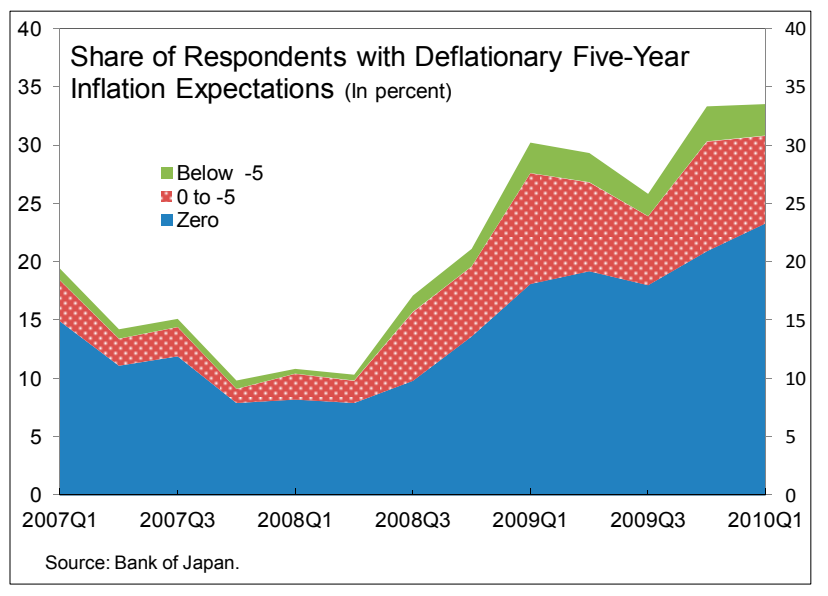


deflation self-propagates by depressing wage growth, discouraging investment, and undermining the fiscal position.

\section{Additional easing measures could address deflation risks and support the} recovery.

- Additional easing. Building on the BoJ's success in lowering short-term interest rates, consideration could be given to extending the size and maturity of its funds supplying operations to 6 months or beyond to reduce still elevated term-spreads. Such action, in turn, might alleviate some appreciation pressures on the exchange rate. In addition, the BoJ could consider purchasing a wider array of assets, such as low-rated corporate bonds, to stimulate activity and help close the output gap.

- $\quad$ Supporting growth. As part of the BoJ's proposal to support growth, consideration could be given to improving access to credit for small and medium-sized enterprises (SME), which are an important source of innovation and change but continue to face financing constraints according to the Tankan survey. For example, the BoJ could broaden the scope of acceptable collateral to include low-rated securitized SME loans, which could encourage the development of a new market for lending to SMEs.

\section{If the recovery falters and deflation worsens, the BoJ could consider a formal quantitative easing framework to stimulate activity and anchor inflation expectations.} Such a move, however, would need to be balanced against the risks that large scale purchases of JGBs without a credible fiscal strategy in place would undermine fiscal discipline and raise sovereign risks.

\section{During this period of heightened uncertainty, clear communication is essential.}

This is especially so in light of a number of administrative price changes (e.g. to high school tuition and tobacco taxes) and the rebasing of the CPI in 2011 which could affect inflation expectations. The BoJ has already clarified that the Policy Board does not "tolerate" year-onyear inflation that is equal to or below zero percent. To further guide expectations, the BoJ could consider communicating its intention to maintain easy monetary conditions until Policy Board members' one-year core inflation forecast exceeds 1 percent (the midpoint of the understanding of price stability) provided that financial imbalances remain absent under the "second perspective." 5

\footnotetext{
5 The BoJ's Policy Board bases its monetary policy on the assessment of economic developments from two perspectives. The first perspective involves analysis of the most likely outlook for economic activity and prices 1-2 years ahead. The second perspective assesses a broad variety of risks to the outlook, including lowprobability but high-cost events (such as asset bubbles) over a longer time horizon.
} 


\section{The Authorities' Views and Policy Intentions}

\section{The BoJ remains open to further policy options, but at this juncture, views its monetary policy stance as appropriate.}

- Deflation. The BoJ viewed deflation as primarily the result of large excess capacity in an environment of structurally low inflation and judged the growing recovery to have contributed to an easing of deflationary pressures. As a result, in its current economic outlook report, Policy Board members projected deflation to end in FY2011, one year earlier than previously anticipated.

- $\quad$ Monetary stance. With the recovery gaining strength, officials thought that the current accommodative monetary policy stance with a virtually zero policy rate was appropriate. Along with the economic recovery and improvement in prices, the stimulating effects of the current easing measures would be more enhanced. Conditions in the commercial paper and corporate bond markets have returned to normal with credit spreads declining and funding constraints appear having abated. As a result, the BoJ saw little benefit from expanding the range of eligible collateral as current facilities already accepted a wide range of financial assets including assetbacked securities and banks were not facing liquidity constraints. Expanding eligibility to include lower-rated assets was unlikely to have a significant impact while raising substantial risks, such as moral hazard and distorting resource allocation.

- $\quad$ Communication. Officials felt that the BoJ's monetary policy communication was effective and that the market had fully internalized the Policy Board's intention of consistently maintaining accommodative monetary conditions. They had reservations about linking the BoJ's policy more explicitly to the inflation outlook and mentioned that recent international experience had underscored that focusing narrowly on inflation could result in overlooking the build-up of financial imbalances. The BoJ reiterated that it remained committed to explaining its monetary stance, assessing both the economic and price outlook and risks from its "two perspectives".

\section{Strengthening the Financial System}

\section{Background}

26. The banking sector has returned to profitability and strengthened its capital position.

- $\quad$ Profitability. Following their first annual loss in five years, both regional and major banks returned to profitability in FY2009. The turnaround mainly reflected a pickup in fee income, lower credit costs, and gains on securities holdings.

- $\quad$ Credit quality. NPL ratios rose for major banks to around 2 percent while falling marginally for regional banks to under 4 percent, partly due to an easing of loan classification criteria in November 2008. 
- $\quad$ Capital ratios. Major banks' Tier-1 ratios have increased to around 9 percent in the first half of FY2009, bolstered by common equity issuances amounting to over $¥ 3$ trillion, while the ratio for regional banks remained stable at 8.7 percent.

\section{Bank lending has been declining since end-2009, partly reflecting weak} corporate demand and a pickup in bond issuances by large companies.

\section{- $\quad$ SME credit. Overall bank lending} has declined, primarily due to weak corporate demand as well as a shift back to market funding by higherrated companies. Meanwhile lending to SMEs continued to contract, despite the earlier expansion of public credit guarantees.

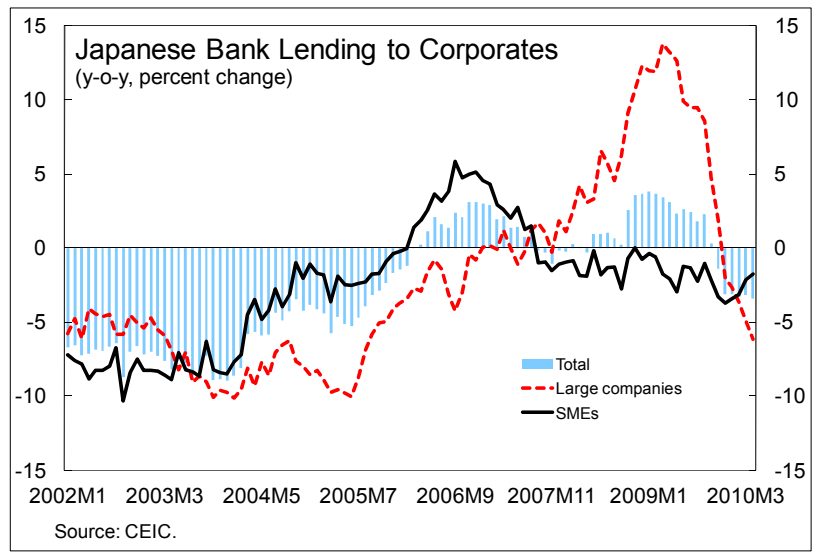

- $\quad J G B$ holdings. As loan demand has fallen, banks have shifted to holding more government bonds, with the share of JGBs in total assets growing from 11 to 16 percent since September 2008.

\section{Policy Issues and Staff views}

\section{The main risks to the financial system are from a slow recovery and increased market volatility.}

- $\quad$ Credit risk. Nonperforming loans could rise if the recovery slows and financial conditions tighten. Prolonged deflation could further undermine bank profitability through low net interest margins. In this environment, supervisors should encourage banks to rigorously monitor credit risks and, where appropriate, take action to restructure distressed borrowers.

- $\quad$ Market risk. Despite the progress in reducing banks' stockholdings (which declined by an estimated 6 percent in FY2009), major banks still carry significant equity exposure as a share of Tier 1 capital (around 50 percent). In contrast, banks, especially regional ones, have increased their exposure to interest rate risk along with their larger JGB holdings. Supervisors should

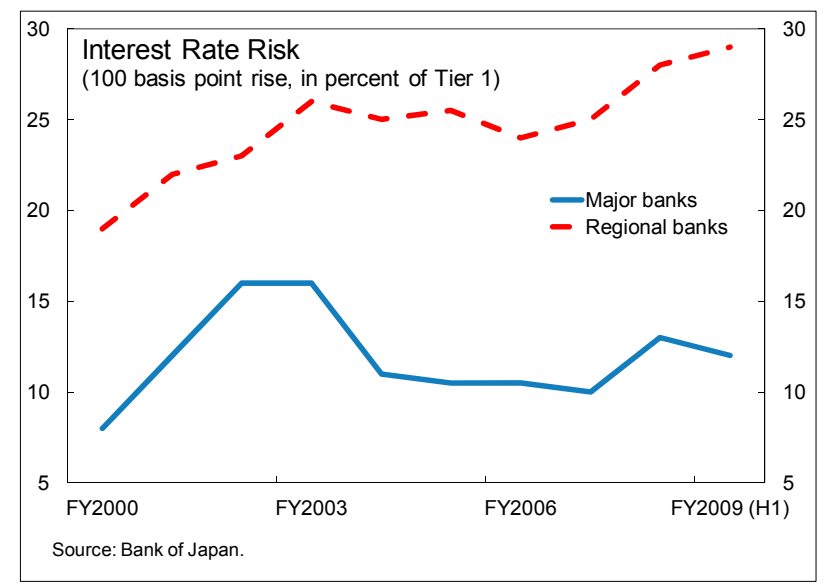
highlight the importance of proper 
risk management and emphasize the need to follow prudential guidelines, as recently done by the FDIC in the United States.

- $\quad$ Spillovers and volatility. Japan's financial system so far has largely been unaffected by recent events in Europe. According to BIS data, Japanese banks' direct exposure to Southern European banks is limited at around $\$ 40$ billion ( $1 / 2$ percent of total assets), but reliance on European cross-border funding is large ( $\$ 484$ billion representing two-thirds of cross-border financing). While Japanese banks thus far have not experienced funding problems, the impact of a sharp pull back by European banks or prolonged market volatility could be substantial U.S. dollar funding pressures (similar to the Lehman shock). In this regard, the BoJ's recent decision to join other central banks in re-establishing US\$ swap facilities with the U.S. Federal Reserve provides a useful backstop.

\section{Japanese banks may need to raise additional capital and boost core profitability} to adjust to changes in global regulations and the domestic environment.

- New global financial regulations. To strengthen the resilience of the financial system, the Basel Committee (BCBS) has proposed strengthening capital standards and limiting leverage. Although the impact will depend on the definition and level of the capital standards and leverage ratios, these changes could have an impact on major banks in Japan who rely relatively heavily on hybrid capital and deferred tax assets or hold significant amounts of JGBs. Although Japanese banks' average leverage ratio, (measured by Tier 1 to total assets) is low by international comparison, banking systems in countries with similar levels of leverage tend to have higher core Tier 1 capital ratios. To ensure financial stability, the authorities should continue to stand ready to inject public funds where necessary and facilitate the consolidation of banks with weak capital bases. ${ }^{6}$

- Japan Post. Proposals to double Japan Post’s deposit ceiling (to ¥20 million) and broaden its range of lending activities would increase the size of an already large financial institution, raising the potential for systemic risk. New lending activities may also weaken profitability of private banks through unfair competition.

\section{The Authorities' Views and Policy Intentions}

30. The authorities broadly shared staff's assessment of the risks and policy directions, and noted that they were monitoring developments closely.

\footnotetext{
${ }^{6}$ The authorities have made $¥ 12$ trillion in public funds available to help banks bolster their capital ratios, of which about $¥ 300$ billion has so far been tapped.
} 
- $\quad$ Credit risk. The authorities shared staff's concerns regarding credit risks, particularly if the recovery should falter. However, they noted that bank credit costs had declined over the last year, and cautioned against impeding the ability of banks to play their intermediary role and support the recovery.

- $\quad$ Interest rate risk. The supervisors acknowledged that the rising share of JGB holdings posed interest rates risks to bank portfolios. The BoJ's March Financial System Report notes that a 100 bps value of interest rate risk relative to Tier 1 has risen to around 12 percent for the major banks and to around 30 percent for the regional banks. To contain these risks, banks are required to adopt appropriate risk management tools, including various stress-tests. On their own part, supervisors were using prudential guidelines to monitor these risks, such as the outlier criteria which flags institutions whose interest rate risk exceeds 20 percent of the sum of Tier 1 and Tier 2 capital.

- $\quad$ Spillovers from Europe. The authorities shared the view that direct risks to Japan's financial system from exposure to Southern European banks were low. Moreover, the recent improvement in profitability had bolstered the resilience of the banking system. Nevertheless, they remain vigilant regarding potential liquidity pressures, particularly if stresses were to spread to other parts of Europe.

- Japan Post. The authorities noted that Japan Post was subject to the same supervisory oversight as private banks. They considered it difficult to predict the impact of the proposed doubling of Japan Post's deposit ceiling, but noted that deposits at Japan Post had declined in recent years indicating that a higher deposit ceiling may have only a limited effect on regional banks. They also expected that as reforms were finalized, the provisionally titled Committee for Postal Reform would ensure a level playing field with respect to private banks in Japan.

31. The authorities stressed the importance of carefully examining the impact of any changes in global financial regulations, especially as the global recovery was still fragile and bank loans were weak. ${ }^{7}$ Imposing additional burden on banks might raise the risks of discouraging bank intermediation. Also uncertainties in future regulations and too abrupt changes in regulatory frameworks might harm banks' lending attitude. The authorities also pointed out that Japanese banks rely less on risky business models and have more stable sources of funding, such as household deposits. With the impact studies on the proposed BCBS reforms still underway, the precise calibration of the new rules not expected before year-end, and extremely limited exposure of Japanese banks' to risky structured products and Southern European government bonds, it was too early to determine whether banks would need additional capital.

\footnotetext{
${ }^{7}$ These topics were discussed in a seminar co-hosted by the OAP and the Japanese Ministry of Finance during the Article IV mission (http://www.imf.org/external/pubs/ft/survey/so/2010/new051910a.htm).
} 


\section{Reforms to Raise Medium-Term Growth}

\section{Policy Issues and Staff Views}

\section{Growth enhancing structural reforms would support fiscal adjustment. In the} outline of the growth strategy (to be finalized in June), the authorities focused on creating new demand in areas such as the environment, health, and technology. Rapid growth in these sectors would make an important contribution towards reaching the government's ambitious long-term real growth target of 2 percent. In addition, supply-side reforms to foster start-ups, boost employment, and raise competition could complement demand measures in boosting medium-term growth (Box 3):

-

Promoting start-ups. Business startup rates are low compared to the United States and have fallen below closure rates since the mid-1990s. Allocating a very small share of public pension assets to venture capital could jump-start this sector and promote start-ups. ${ }^{8}$ Reorienting public support systems away from credit guarantee on SME loans to reforms that promote more risk-

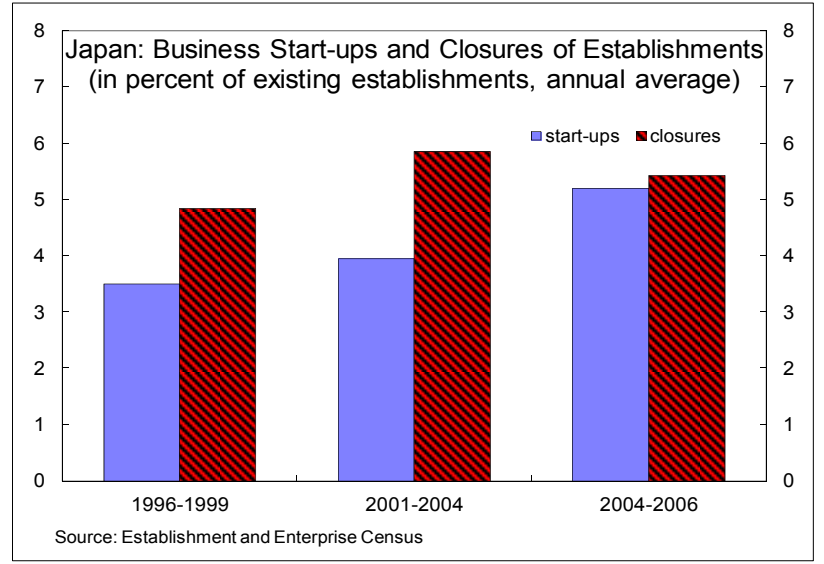
based (as opposed to guarantee based) lending could also help nurture start-ups during their early development.

- $\quad$ Boosting employment. Staff supports the authorities' plans to raise female labor force participation by addressing workplace needs for families with children. Introducing a new, more flexible regular labor contract could improve employment by encouraging new hires, especially among temporary workers.

\footnotetext{
${ }^{8}$ Presently, the Government Pension Investment Fund (GPIF) does not undertake any alternative investments (such as venture capital, real estate and private equity). By contrast, a number of OECD countries allocate nontrivial shares of their assets to such investments, including CalPERS in the U.S. (14 percent), New Zealand Superannuation Fund (11 percent), Government of Singapore Investment Corporation (11 percent), and Korea National Pension Service Fund (2.5 percent).
} 


\section{Box 3. Exploring Supply-Side Reforms to Raise Growth}

This box summarizes policy options to boost consumption and investment, which are discussed in more detail in two Selected Issues chapters. ${ }^{1}$

Private consumption. Japan's private consumption share at 55 percent of GDP is low compared to the G-7 (versus 60 percent). Weak consumption reflects stagnant disposable income, in particular wages, and low household property income (representing 4 percent of disposable income in 2007 compared to 20 percent in the United States). To stimulate private consumption, wages and property income could be supported by:

- Service deregulation. Raising productivity in services, particularly in health care, would boost wages and corporate profits, which in turn could further boost income through higher stock returns and dividend payouts.

- Labor reform. Creating a new regular contract with weaker employment protection could encourage firms to hire more regular workers. This would not only lead to more human capital investment, but might also address concerns about inequity between regular and non-regular workers.

- Aged support. In addition, new retirement divestment instruments for the elderly could boost spending. For example, promoting reverse home
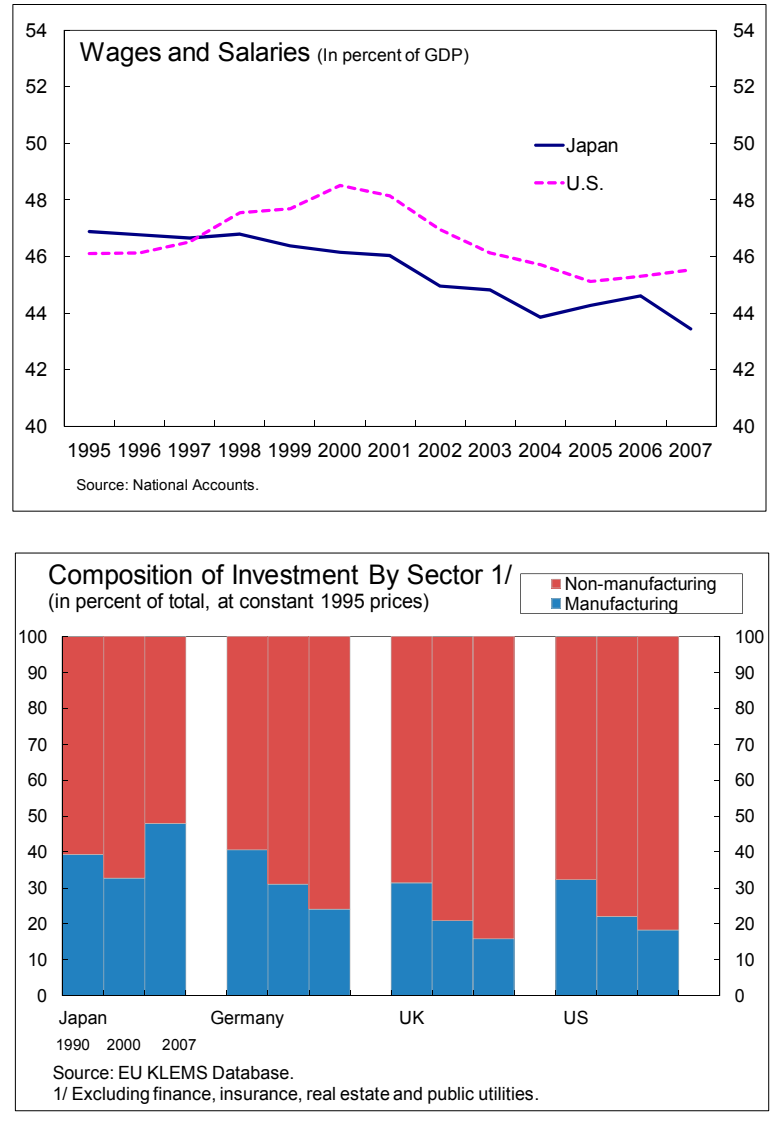
mortgages could help retirees to access home equity but may require public support as for instance in the United States, where insurance to banks is provided.

Business investment. At 23 percent of GDP, aggregate investment in Japan is close to the OECD average, but the share of investment by SMEs and firms in the services sector-the main source of employment in Japan - has fallen significantly. Staff analysis suggests that this is largely due to credit constraints and that despite progress with financial restructuring, excess leverage and dependence on debt financing has held back investment. Germany displays a similar pattern, but there is less evidence of financing constraints or detrimental effects of debt for U.S. and U.K. firms in recent years.

Promoting investment by SMEs and firms in the services sector would provide an additional engine of growth. Priorities should include promoting more risk-based (as opposed to collateral-based) lending; measures to facilitate a wider range of securitization (beyond real estate and other fixed assets); and widening the pool of venture capital funding for start-ups. Investment could also be strengthened by facilitating restructuring, including through phasing out full credit guarantees and assisting the exit of nonviable companies through out-of-court workouts and further bankruptcy reforms.

\footnotetext{
1 "Boosting Private Consumption in Japan" and "Raising Medium-Term Growth: What Role can Investment Play?"
} 
- $\quad$ Increasing competition. Further deregulation and market opening, particularly in health, childcare, and other services, would give a boost to productivity and make Japan a more attractive destination for foreign investment.

\section{The Authorities' Views and Policy Intentions}

33. The authorities view the growth strategy as important to help support the fiscal adjustment. While full details of the growth strategy had yet to be agreed, the authorities recognized that some of the reforms put forth by the staff-specifically, to foster start-ups and boost employment_ could complement their own efforts.

- $\quad$ Start-ups. The authorities broadly agreed with staff's assessment regarding Japan's low business start-up rates and limited venture capital, but expressed reservations about staff's policy suggestions regarding the use of public assets. The authorities cautioned against making venture capital investments with public pension assets, noting that the level of risk may not be appropriate for public funds. While recognizing that reforms are needed to increase risk-based lending to SMEs, the authorities view credit guarantees as an effective tool to support SME employment, which accounts for almost 70 percent of the labor force.

- $\quad$ Boosting employment. The authorities were optimistic about measures to increase female participation in the labor force by both addressing workplace needs for families with children and introducing policies that would increase the supply of childcare services. The authorities also shared staff's concerns about the widening gap between regular and non-regular workers.

\section{EXChange Rate, EXternal Stability, AND SpIllovers}

34. Based on staff analysis, the current value of the yen is consistent with mediumterm fundamentals. The yen has appreciated significantly in real terms during the crisis but remained broadly constant during late 2009 and early 2010.

- $\quad$ Exchange rate assessment. In terms of the IMF's Consultative Group on Exchange Rates (CGER)'s three analytical methods, the yen's effective exchange rate is estimated close to its medium-term equilibrium value as of March 2010 . The real effective exchange rate is also currently close to its long-term average since 1990.

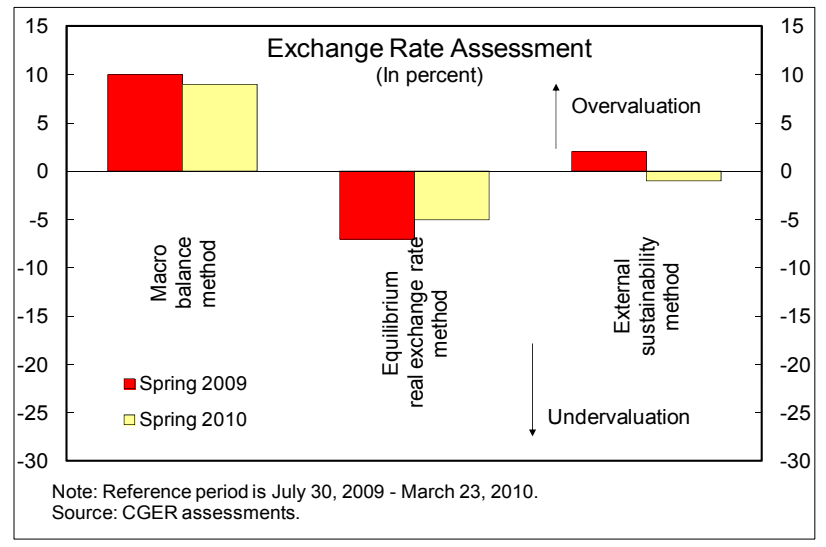


- Exchange rate framework. Despite the yen's appreciation, the authorities have not intervened in foreign exchange markets. The staff continues to support the official policy that the exchange rate should be market determined, with intervention only justified to counter disruptive exchange rate movements.

35. Risks to external stability are currently limited, but heightened risk aversion could lead to disorderly capital flows. A sustained increase in risk aversion could unwind yen-carry trades leading to further yen appreciation. Corporates with large holdings of foreign assets could also begin repatriating overseas funds.

36. Over the medium term, Japan's current account surplus will likely remain close to its equilibrium level with modest growth spillovers to the region. The medium-term current account balance is projected at around 2 percent of GDP, below levels seen earlier this decade ( $3 \frac{1}{2}$ percent during 2002-07) owing to lower export demand and population aging. ${ }^{9}$ The narrowing current account surplus will help facilitate global rebalancing, although a sizeable fiscal consolidation, if realized, would lead to a larger current account surplus. Growth spillovers to the region could be negative in the near-term, as fiscal adjustment would restrain import demand, but over the longer term positive confidence effects of consolidation could boost domestic and import demand.

\section{The authorities broadly shared staff's medium-term outlook for external}

balances. They noted that the recent global turmoil and safe haven flows had pushed the yen higher and this could hurt competitiveness if it persisted.

\section{StAFf APPRAISAL}

38. Timely stimulus and strong external demand have supported the economic recovery. With the output gap gradually closing, deflationary pressures have begun to ease. The outlook, however, is subject to considerable uncertainty and risks due to global sovereign debt concerns. If risk aversion intensifies, further yen appreciation and falling external demand could weaken the recovery.

39. Global events have sharpened the focus on Japan's fiscal problems and raised the urgency for credible fiscal adjustment. In this light, fiscal adjustment should begin next year centered around a gradual increase in the consumption tax and followed by a sustained reduction in the structural primary deficit over the next decade. Sustained consolidation will require comprehensive tax reform, limits on non-social security spending growth, and entitlement reforms. A fiscal rule featuring a public debt cap and a primary surplus target could strengthen credibility and lock-in fiscal gains.

\footnotetext{
${ }^{9}$ The current account norm is estimated 2.8 percent of GDP, and the current account stabilizing NFA at 2009 level is 1.7 percent of GDP.
} 
40. Further easing measures by the BoJ could support the recovery and address the risks of deflation intensifying. To stimulate activity, the BoJ could extend the maturity of its funds supplying operations and broaden asset purchases. In a period of heightened uncertainty, clear communication will also be critical. To better guide expectations, the BoJ could communicate a stronger intention to maintain policy accommodation until its one-year core inflation forecast is one percent or above, provided that financial imbalances remain absent.

41. The banking sector has continued to improve, but faces a number of challenges. Banks have returned to profitability and bolstered their capital bases, but risks remain from a slow recovery and market volatility particularly that emanating from overseas markets. Banks also face challenges in adapting to new global financial standards. Under these circumstances, the authorities should ensure that banks follow proper risk management and stand ready to assist banks, where necessary, in strengthening their financial positions.

42. An ambitious pro-growth agenda would help support fiscal adjustment. The government's new growth strategy aims to promote demand in areas such as the environment, health and technology. In addition, supply-side reforms to promote start-ups, boost employment, and increase competition, especially in services, could complement demand measures in boosting medium-term growth.

43. It is recommended that the next Article IV consultation take place on the standard 12-month cycle. 
Table 1. Japan: Selected Economic Indicators, 2006-11

Nominal GDP: US $\$ 5,068$ billion (2009)

Population: 127.6 million (2009)

GDP per capita: US\$39,730 (2009)

Quota: SDR 13,312.8 million

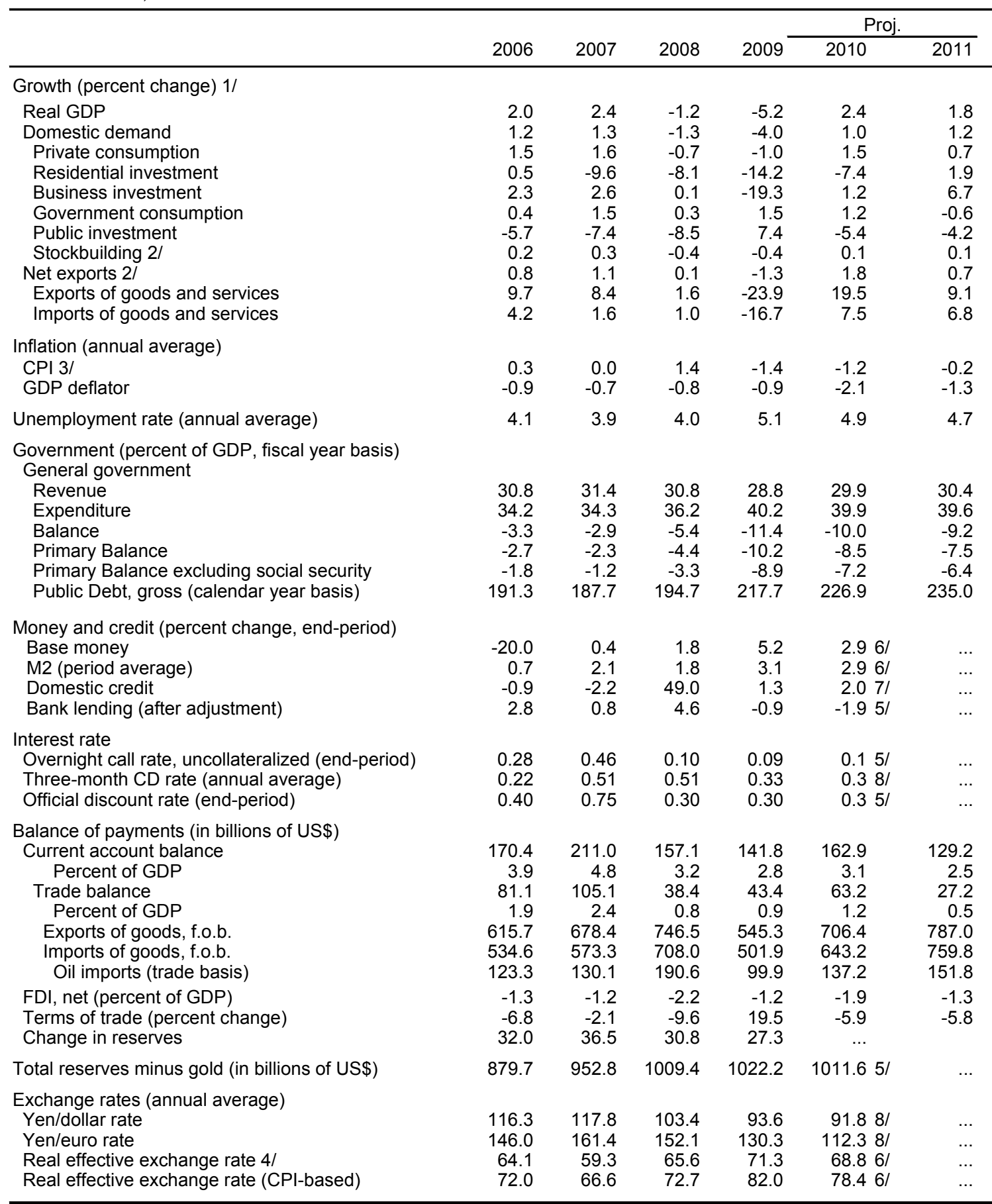

Sources: Global Insight, Nomura database; IMF, Competitiveness Indicators System; and Fund staff estimates and projections as of June 14, 2010.

1/ Annual growth rates and contributions are calculated from seasonally adjusted data.

2/ Contribution to GDP growth.

3/ Based on published annual averages of the $\mathrm{CPI}$ index.

4/ Based on normalized unit labor costs; $2000=100$.

5/ May 2010

6/ April 2010.

7/ March 2010.

8/ June 14, 2010. 
Table 2. Japan: General Government Operations, 2005-2011 1/

\begin{tabular}{|c|c|c|c|c|c|c|c|}
\hline & 2005 & 2006 & 2007 & 2008 & 2009 & $\begin{array}{l}2010 \\
\text { Proj. }\end{array}$ & $\begin{array}{l}2011 \\
\text { Proj. }\end{array}$ \\
\hline & \multicolumn{7}{|c|}{ (Fiscal year) } \\
\hline Total revenue & 29.9 & 30.8 & 31.3 & 30.8 & 28.8 & 29.9 & 30.4 \\
\hline $\begin{array}{l}\text { Taxes and fines } \\
\text { Social security premiums } \\
\text { Property income }\end{array}$ & $\begin{array}{r}17.3 \\
10.6 \\
1.8\end{array}$ & $\begin{array}{r}17.8 \\
10.8 \\
2.0\end{array}$ & $\begin{array}{r}18.0 \\
11.0 \\
2.0\end{array}$ & $\begin{array}{r}17.2 \\
11.5 \\
1.7\end{array}$ & $\begin{array}{r}15.2 \\
11.7 \\
1.6\end{array}$ & $\begin{array}{r}16.3 \\
11.8 \\
1.5\end{array}$ & $\begin{array}{r}16.6 \\
12.0 \\
1.5\end{array}$ \\
\hline Total expenditure & 34.2 & 34.2 & 34.3 & 36.2 & 40.2 & 39.9 & 39.6 \\
\hline $\begin{array}{l}\text { Current } \\
\text { Consumption } \\
\text { (less) Depreciation } \\
\text { Social security benefits } \\
\text { Other current } \\
\text { Interest paid }\end{array}$ & $\begin{array}{r}30.7 \\
11.6 \\
-3.1 \\
16.2 \\
3.5 \\
2.4\end{array}$ & $\begin{array}{r}30.5 \\
11.5 \\
-3.1 \\
16.3 \\
3.4 \\
2.5\end{array}$ & $\begin{array}{r}31.1 \\
11.5 \\
-3.2 \\
16.7 \\
3.6 \\
2.5\end{array}$ & $\begin{array}{r}32.9 \\
12.1 \\
-3.3 \\
17.7 \\
3.9 \\
2.6\end{array}$ & $\begin{array}{r}36.7 \\
12.6 \\
-3.2 \\
18.8 \\
5.7 \\
2.8\end{array}$ & $\begin{array}{r}36.6 \\
12.6 \\
-3.2 \\
19.2 \\
5.0 \\
3.0\end{array}$ & $\begin{array}{r}36.4 \\
12.2 \\
-3.2 \\
19.3 \\
4.9 \\
3.1\end{array}$ \\
\hline $\begin{array}{l}\text { Capital } \\
\text { Investment } \\
\text { Land acquisition } \\
\text { Capital transfers } \\
\text { Of which: Bank support } \\
\text { Balance }\end{array}$ & $\begin{array}{r}3.6 \\
3.6 \\
0.4 \\
-0.4 \\
0.0 \\
-4.3\end{array}$ & $\begin{array}{r}3.7 \\
3.2 \\
0.4 \\
0.0 \\
0.0 \\
-3.3\end{array}$ & $\begin{array}{r}3.2 \\
3.0 \\
0.4 \\
-0.2 \\
0.0 \\
-2.9\end{array}$ & $\begin{array}{r}3.3 \\
3.1 \\
0.4 \\
-0.2 \\
0.0 \\
-5.4\end{array}$ & $\begin{array}{r}3.6 \\
3.2 \\
0.4 \\
-0.1 \\
0.0 \\
-11.4\end{array}$ & $\begin{array}{r}3.3 \\
3.0 \\
0.4 \\
0.0 \\
0.0 \\
-10.0\end{array}$ & $\begin{array}{r}3.2 \\
2.9 \\
0.4 \\
0.0 \\
0.0 \\
-9.2\end{array}$ \\
\hline $\begin{array}{l}\text { Primary balance } \\
\text { Excluding social security }\end{array}$ & $\begin{array}{l}-3.6 \\
-2.9\end{array}$ & $\begin{array}{l}-2.7 \\
-1.8\end{array}$ & $\begin{array}{l}-2.3 \\
-1.2\end{array}$ & $\begin{array}{l}-4.4 \\
-3.3\end{array}$ & $\begin{array}{r}-10.2 \\
-8.9\end{array}$ & $\begin{array}{l}-8.5 \\
-7.2\end{array}$ & $\begin{array}{l}-7.5 \\
-6.4\end{array}$ \\
\hline \multirow[t]{2}{*}{ Structural balance 2/ } & -4.0 & -3.4 & -3.1 & -4.0 & -8.8 & -7.8 & -7.8 \\
\hline & \multicolumn{7}{|c|}{ (Calendar year) } \\
\hline Total revenue & 29.4 & 30.7 & 31.0 & 31.5 & 29.5 & 29.8 & 30.3 \\
\hline $\begin{array}{l}\text { Taxes and fines } \\
\text { Social security premiums } \\
\text { Property income }\end{array}$ & $\begin{array}{r}16.8 \\
10.6 \\
1.7\end{array}$ & $\begin{array}{r}17.7 \\
10.8 \\
1.9\end{array}$ & $\begin{array}{r}17.9 \\
10.9 \\
2.0\end{array}$ & $\begin{array}{r}18.0 \\
11.3 \\
1.8\end{array}$ & $\begin{array}{r}15.7 \\
11.8 \\
1.6\end{array}$ & $\begin{array}{r}16.2 \\
11.8 \\
1.5\end{array}$ & $\begin{array}{r}16.6 \\
12.0 \\
1.5\end{array}$ \\
\hline Total expenditure & 34.2 & 34.7 & 33.4 & 35.6 & 39.8 & 39.6 & 39.6 \\
\hline $\begin{array}{l}\text { Current } \\
\text { Consumption } \\
\text { (less) Depreciation } \\
\text { Social security benefits } \\
\text { Other current } \\
\text { Interest paid }\end{array}$ & $\begin{array}{r}30.7 \\
11.7 \\
-3.1 \\
16.1 \\
3.6 \\
2.4\end{array}$ & $\begin{array}{r}30.6 \\
11.5 \\
-3.1 \\
16.4 \\
3.4 \\
2.4\end{array}$ & $\begin{array}{r}30.7 \\
11.4 \\
-3.2 \\
16.5 \\
3.4 \\
2.5\end{array}$ & $\begin{array}{r}31.9 \\
11.8 \\
-3.4 \\
17.2 \\
3.7 \\
2.5\end{array}$ & $\begin{array}{r}36.2 \\
12.6 \\
-3.4 \\
18.7 \\
5.5 \\
2.8\end{array}$ & $\begin{array}{r}36.2 \\
12.6 \\
-3.4 \\
19.1 \\
5.0 \\
2.9\end{array}$ & $\begin{array}{r}36.3 \\
12.3 \\
-3.4 \\
19.4 \\
4.9 \\
3.1\end{array}$ \\
\hline $\begin{array}{l}\text { Capital } \\
\text { Investment } \\
\text { Land acquisition } \\
\text { Capital transfers } \\
\text { Of which: Bank support }\end{array}$ & $\begin{array}{r}3.5 \\
3.6 \\
0.4 \\
-0.5 \\
0.0\end{array}$ & $\begin{array}{l}4.1 \\
3.3 \\
0.4 \\
0.3 \\
0.0\end{array}$ & $\begin{array}{r}2.7 \\
3.1 \\
0.4 \\
-0.8 \\
0.0\end{array}$ & $\begin{array}{l}3.8 \\
3.0 \\
0.4 \\
0.4 \\
0.0\end{array}$ & $\begin{array}{r}3.5 \\
3.2 \\
0.4 \\
-0.1 \\
0.0\end{array}$ & $\begin{array}{r}3.4 \\
3.0 \\
0.4 \\
-0.1 \\
0.0\end{array}$ & $\begin{array}{l}3.2 \\
2.9 \\
0.4 \\
0.0 \\
0.0\end{array}$ \\
\hline Balance & -4.8 & -4.0 & -2.4 & -4.1 & -10.3 & -9.8 & -9.2 \\
\hline $\begin{array}{l}\text { Primary balance } \\
\text { Excluding social security } \\
\text { Structural balance } 2 /\end{array}$ & $\begin{array}{l}-4.0 \\
-3.5 \\
-4.5\end{array}$ & $\begin{array}{l}-3.4 \\
-2.6 \\
-3.9\end{array}$ & $\begin{array}{l}-1.8 \\
-0.8 \\
-2.5\end{array}$ & $\begin{array}{l}-3.2 \\
-2.3 \\
-3.5\end{array}$ & $\begin{array}{l}-9.1 \\
-7.8 \\
-7.3\end{array}$ & $\begin{array}{l}-8.3 \\
-7.1 \\
-7.7\end{array}$ & $\begin{array}{l}-7.6 \\
-6.4 \\
-7.6\end{array}$ \\
\hline $\begin{array}{l}\text { Debt (In percent of GDP, calenda } \\
\text { Gross } \\
\text { Net }\end{array}$ & $\begin{array}{r}191.6 \\
84.6\end{array}$ & $\begin{array}{r}191.3 \\
84.3\end{array}$ & $\begin{array}{r}187.7 \\
81.5\end{array}$ & $\begin{array}{r}194.7 \\
94.9\end{array}$ & $\begin{array}{l}217.7 \\
111.6\end{array}$ & $\begin{array}{l}226.9 \\
121.4\end{array}$ & $\begin{array}{l}235.0 \\
130.3\end{array}$ \\
\hline $\begin{array}{l}\text { Memorandum items: } \\
\text { Nominal GDP (FY, trillion yen) } \\
\text { Nominal GDP (CY, trillion yen) }\end{array}$ & $\begin{array}{l}503.2 \\
501.7\end{array}$ & $\begin{array}{l}510.9 \\
507.4\end{array}$ & $\begin{array}{l}515.6 \\
515.5\end{array}$ & $\begin{array}{l}494.9 \\
505.1\end{array}$ & $\begin{array}{l}476.3 \\
474.2\end{array}$ & $\begin{array}{l}474.3 \\
475.5\end{array}$ & $\begin{array}{l}481.1 \\
477.7\end{array}$ \\
\hline
\end{tabular}

Source: Fund staff estimates.

1/ Estimated from the National Income Accounts data. The fiscal year is April through March.

2/ Excluding bank support. 
Table 3. Japan: External and Financial Indicators, 2005-10

(In percent of GDP, unless otherwise indicated)

\begin{tabular}{|c|c|c|c|c|c|c|}
\hline & 2005 & 2006 & 2007 & 2008 & 2009 & $\begin{array}{r}\text { Latest } \\
2010\end{array}$ \\
\hline \multicolumn{7}{|l|}{ External indicators } \\
\hline Real exports of goods and services (percent change) & 7.0 & 9.7 & 8.4 & 1.6 & -23.9 & $\ldots$ \\
\hline Real imports of goods and services (percent change) & 5.8 & 4.2 & 1.6 & 1.0 & -16.7 & $\ldots$ \\
\hline Terms of trade (percent change) & -5.2 & -6.8 & -2.1 & -9.6 & 19.5 & $\ldots$ \\
\hline Current account balance & 3.6 & 3.9 & 4.8 & 3.2 & 2.8 & $\ldots$ \\
\hline Capital and financial account balance & -2.7 & -2.5 & -4.4 & -4.2 & -2.9 & $\ldots$ \\
\hline \multicolumn{7}{|l|}{ Of which: } \\
\hline Inward portfolio investment & 4.0 & 4.6 & 4.5 & -2.2 & -1.1 & $\ldots$ \\
\hline Inward direct investment & 0.1 & -0.1 & 0.5 & 0.5 & 0.2 & $\ldots$ \\
\hline Other investment liabilities (net) & -1.4 & -4.0 & -4.7 & 4.2 & 2.7 & $\ldots$ \\
\hline Total reserves minus gold (US\$ billion) & 834.3 & 879.7 & 952.8 & 1009.4 & 1022.2 & 1011.6 \\
\hline In months of imports of goods and services & 17.0 & 16.3 & 16.4 & 14.3 & 19.8 & $\ldots$ \\
\hline Broad money (M2 + CDs) to reserves ratio & 0.8 & 0.7 & 0.6 & 0.7 & 0.8 & 0.8 \\
\hline Foreign assets of DMBs (US\$ billion) & 1283.0 & 1200.9 & 1369.9 & 1778.7 & $\ldots$ & $\ldots$ \\
\hline Foreign liabilities of DMBs (US\$ billion) & 831.2 & 759.4 & 765.9 & 1077.5 & $\ldots$ & $\ldots$ \\
\hline Net international investment position (US\$ billion) & 1639.5 & 1849.4 & 2125.0 & 2181.8 & 2845.2 & $\ldots$ \\
\hline \multicolumn{7}{|l|}{ Of which: } \\
\hline External loan liabilities & 860.2 & 733.9 & 721.1 & 739.9 & 873.7 & $\ldots$ \\
\hline External public sector debt (gross) $1 /$ & 383.2 & 422.3 & 581.0 & 620.6 & $\ldots$ & $\ldots$ \\
\hline External loan liabilities to exports ratio & 1.3 & 1.0 & 0.9 & 0.9 & 1.4 & $\ldots$ \\
\hline External interest payments to exports (in percent) $2 /$ & 1.7 & 2.5 & 2.5 & 1.9 & 1.6 & $\ldots$ \\
\hline Nominal effective exchange rate (percent change, period avg) & -3.1 & -7.0 & -5.0 & 12.4 & 14.6 & 1.1 \\
\hline \multicolumn{7}{|l|}{ Financial market indicators } \\
\hline General government gross debt & 191.6 & 191.3 & 187.7 & 194.7 & 217.7 & $\ldots$ \\
\hline \multicolumn{7}{|l|}{ Interest rates (percent, end-year) } \\
\hline 3-month General collateral repo rate 3/ & 0.01 & 0.47 & 0.60 & 0.22 & 0.13 & 0.12 \\
\hline 3-month General collateral repo rate, real 3/ & 0.41 & 0.17 & -0.10 & -0.18 & 0.13 & 1.31 \\
\hline 3-month interest rate spread vis-à-vis U.S. & -3.88 & -4.37 & -4.36 & -4.80 & 0.13 & -0.04 \\
\hline Stock market index (TOPIX, percent change, end-year) 4/ & 43.5 & 1.9 & -12.2 & -41.8 & 5.6 & -1.9 \\
\hline \multicolumn{7}{|l|}{ Banking sector risk indicators } \\
\hline Total loans to assets (in percent) & 31.0 & 28.6 & 26.9 & 27.9 & 27.8 & $\ldots$ \\
\hline Total loans to deposits (in percent) & 78.4 & 79.5 & 77.5 & 79.2 & 75.9 & $\ldots$ \\
\hline Share of real estate sector in total lending (in percent) & 16.5 & 18.9 & 19.2 & 19.0 & 20.6 & $\ldots$ \\
\hline \multicolumn{7}{|l|}{ Share of nonperforming loans in total loans } \\
\hline (In percent, end-fiscal year) 5/ & 1.8 & 1.5 & 1.4 & 1.7 & 1.9 & $\ldots$ \\
\hline Risk-weighted capital ratio (in percent, end-fiscal year) 5/ 6/ & 12.2 & 13.1 & 12.3 & 12.4 & 14.3 & $\ldots$ \\
\hline
\end{tabular}

Sources: Global Insight, Nomura Database; IMF, International Financial Statistics; Fitch IBCA;

and Fund staff estimates.

1/ Public sector debt securities and other loan liabilities.

2/ Other investment income, debit.

3/ 3-month Tokyo repo rate since October 2007.

4/ Twelve-month percent change for the latest figure.

$5 /$ Major banks. Capital ratio is on a nonconsolidated basis.

6/ 2009 refers to first half of FY2009. 
Table 4. Japan: Balance of Payments, 2004-09

\begin{tabular}{|c|c|c|c|c|c|c|}
\hline & 2004 & 2005 & 2006 & 2007 & 2008 & 2009 \\
\hline & \multicolumn{6}{|c|}{ (In billions of U.S. dollars) } \\
\hline Current account & 172.1 & 165.7 & 170.4 & 211.0 & 157.1 & 141.8 \\
\hline Trade balance & 128.5 & 93.8 & 81.1 & 105.1 & 38.4 & 43.4 \\
\hline Exports & 539.1 & 567.4 & 615.7 & 678.4 & 746.5 & 545.3 \\
\hline Imports & 410.6 & 473.6 & 534.6 & 573.3 & 708.0 & 501.9 \\
\hline Invisibles & 43.6 & 71.8 & 89.3 & 105.9 & 118.6 & 98.4 \\
\hline Nonfactor services & -34.3 & -24.1 & -18.2 & -21.2 & -20.8 & -20.4 \\
\hline Investment income & 85.8 & 103.6 & 118.2 & 138.7 & 152.6 & 131.1 \\
\hline \multirow[t]{2}{*}{ Net transfers } & -7.9 & -7.6 & -10.7 & -11.6 & -13.1 & -12.3 \\
\hline & \multicolumn{6}{|c|}{ (In percent of GDP) } \\
\hline Current account & 3.7 & 3.6 & 3.9 & 4.8 & 3.2 & 2.8 \\
\hline Trade balance & 2.8 & 2.1 & 1.9 & 2.4 & 0.8 & 0.9 \\
\hline Invisibles & 0.9 & 1.6 & 2.0 & 2.4 & 2.4 & 1.9 \\
\hline Nonfactor services & -0.7 & -0.5 & -0.4 & -0.5 & -0.4 & -0.4 \\
\hline Investment income & 1.9 & 2.3 & 2.7 & 3.2 & 3.1 & 2.6 \\
\hline \multirow[t]{2}{*}{ Net transfers } & -0.2 & -0.2 & -0.2 & -0.3 & -0.3 & -0.2 \\
\hline & \multicolumn{6}{|c|}{ (In billions of U.S. dollars) } \\
\hline Capital account & -4.8 & -4.9 & -4.7 & -4.1 & -5.6 & -5.0 \\
\hline Financial account & -138.5 & -144.8 & -134.7 & -224.3 & -204.6 & -158.2 \\
\hline Direct investment, net & -23.3 & -42.2 & -56.7 & -51.7 & -106.2 & -62.5 \\
\hline Direct investment abroad & -31.1 & -45.4 & -50.2 & -73.7 & -130.9 & -74.2 \\
\hline Foreign direct investment in Japan & 7.8 & 3.2 & -6.4 & 22.0 & 24.7 & 11.7 \\
\hline Portfolio investment, net & 24.6 & -12.0 & 127.4 & 68.3 & -298.7 & -217.5 \\
\hline Of which: Official & 95.1 & 52.6 & 104.6 & 177.5 & -27.2 & -77.0 \\
\hline Inflows & -173.7 & -196.2 & -71.8 & -127.2 & -191.8 & -161.4 \\
\hline Outflows & 198.3 & 184.1 & 199.2 & 195.4 & -106.8 & -56.1 \\
\hline Other investment, net & 21.1 & -68.2 & -173.4 & -204.4 & 231.0 & 149.1 \\
\hline Of which: Official & 4.1 & 25.6 & -24.8 & 0.4 & 111.5 & -119.4 \\
\hline Inflows & 8.1 & 122.5 & 57.6 & -65.9 & 420.4 & 535.8 \\
\hline Outflows & 13.0 & -190.7 & -231.0 & -138.5 & -189.4 & -386.7 \\
\hline Reserve assets & -161.0 & -22.3 & -32.0 & -36.5 & -30.8 & -27.3 \\
\hline Errors and omissions, net & -28.8 & -16.1 & -31.0 & 17.4 & 53.1 & 21.4 \\
\hline \multicolumn{7}{|l|}{ Memorandum items: } \\
\hline Nominal GDP (US\$ billion) & 4608.3 & 4561.3 & 4364.5 & 4380.2 & 4894.7 & 5071.1 \\
\hline Net foreign assets (NFA)/GDP & 39.8 & 43.9 & 49.7 & 54.0 & 52.3 & 52.9 \\
\hline Return on NFA (In percent) & 4.7 & 5.2 & 5.5 & 5.9 & 6.0 & 4.9 \\
\hline
\end{tabular}

Sources: Global Insight, Nomura database; and Fund staff estimates. 
Table 5. Japan: Medium-Term Projections, 2008-15

(Percentage change from the previous period, unless otherwise indicated)

\begin{tabular}{|c|c|c|c|c|c|c|c|c|c|c|c|c|}
\hline & 2004 & 2005 & 2006 & 2007 & 2008 & 2009 & 2010 & 2011 & 2012 & 2013 & 2014 & 2015 \\
\hline Real GDP & 2.7 & 1.9 & 2.0 & 2.3 & -0.7 & -5.3 & 2.4 & 1.8 & 2.0 & 1.9 & 1.8 & 1.7 \\
\hline Total domestic demand & 1.9 & 1.8 & 1.2 & 1.3 & -1.3 & -4.0 & 1.0 & 1.2 & 1.6 & 1.5 & 1.5 & 1.5 \\
\hline Net exports (contribution) & 0.8 & 0.3 & 0.8 & 1.1 & 0.2 & -2.0 & 1.8 & 0.7 & 0.5 & 0.5 & 0.4 & 0.3 \\
\hline Unemployment rate (percent) & 4.7 & 4.4 & 4.1 & 3.9 & 4.0 & 5.1 & 4.9 & 4.7 & 4.5 & 4.3 & 4.2 & 4.1 \\
\hline CPI inflation & 0.0 & -0.3 & 0.3 & 0.0 & 1.4 & -1.4 & -1.2 & -0.2 & 0.3 & 0.6 & 0.8 & 1.0 \\
\hline Output gap & & & & 0.4 & -1.6 & -7.2 & -5.2 & -3.9 & -2.6 & -1.5 & -0.6 & 0.1 \\
\hline Overall fiscal balance (fiscal years) $1 /$ & & -4.3 & -3.3 & -2.9 & -5.4 & -11.4 & -10.0 & -9.2 & -8.8 & -8.0 & -7.6 & -7.4 \\
\hline Primary balance & & -3.6 & -2.7 & -2.3 & -4.4 & -10.2 & -8.5 & -7.5 & -7.0 & -5.9 & -5.3 & -5.0 \\
\hline Primary balance excl. social security & & -2.9 & -1.8 & -1.2 & -3.3 & -8.9 & -7.2 & -6.4 & -5.7 & -4.5 & -3.8 & -3.2 \\
\hline \multicolumn{13}{|l|}{ Debt (calendar years) $1 /$} \\
\hline Gross & & 191.6 & 191.3 & 187.7 & 194.7 & 217.7 & 226.9 & 235.0 & 240.0 & 244.2 & 247.1 & 249.8 \\
\hline Net & & 84.6 & 84.3 & 81.5 & 94.9 & 111.6 & 121.4 & 130.3 & 137.2 & 143.5 & 148.9 & 154.3 \\
\hline Current Account Balance 1/ & 3.7 & 3.6 & 3.9 & 4.8 & 3.2 & 2.8 & 3.1 & 2.5 & 2.3 & 2.2 & 2.1 & 2.0 \\
\hline
\end{tabular}

Sources: Global Insight, Nomura database; and Fund staff estimates.

$1 /$ In percent of GDP. 


\section{Appendix I. Japan: Public Sector Debt Sustainability ${ }^{10}$}

Staff has updated its assessment of Japan's public debt sustainability. This annex looks at three scenarios: i) a no adjustment scenario which leads to a continued rise in the net debt ratio; ii) a policy adjustment scenario that would reduce the net debt GDP ratio to 100 percent by 2030; and iii) a delayed and more gradual adjustment scenario, where the net debt ratio would remain at an unsustainably high level long into the future.

Macroeconomic assumptions. Both real GDP growth and the inflation rate are assumed to converge to 1 percent over the long term (as a result, nominal GDP growth is around 2 percent per year over the next 10 years). The nominal interest rate growth differential is assumed to converge to $1 \frac{1}{4}$ percent (pre-crisis average since 2000) over the long run. ${ }^{11}$

No adjustment scenario. With no adjustment, net public debt would rise and approach 250 percent of GDP by 2030. The no adjustment scenario assumes withdrawal of stimulus (1 $1 \frac{2}{2}$ percent of GDP), a modest expenditure adjustment ( 1 percent of GDP), and unchanged tax policy (no increase in the consumption tax) over the next 10 years, which altogether produces an improvement of $2 \frac{1}{2}$ percent of GDP in the structural primary balance.

Policy adjustment scenario. Achieving debt sustainability will require that Japan stabilize and put its debt-to-GDP ratio firmly on a downward path. To achieve this goal, the policy adjustment scenario assumes a 10 percent of GDP improvement of the structural primary balance between 2010 and 2020. This comprises of a withdrawal of stimulus ( $1 \frac{1}{2}$ percent of GDP) plus additional policy measures of 8.5 percent of GDP, of which 4.5 percentage points are assumed to come

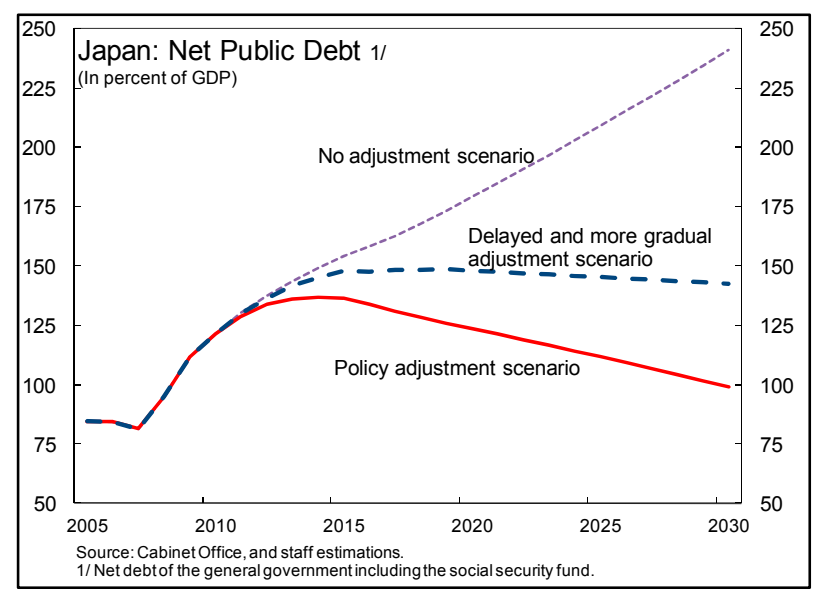
from a net tax increase including a gradual consumption tax hike starting in $2011^{12}$ and 4 percentage points from expenditure reforms (by freezing non social security spending in nominal terms and limiting growth in social security spending).

\footnotetext{
${ }^{10}$ The analyses focus on net debt of the general government including the social security fund.

${ }^{11}$ Consequently, nominal interest rates are assumed to rise to $3 \frac{1}{4}$ percent (compared to 1.3 percent currently) over the long run, while growth remains at its 1 percent potential.

${ }^{12}$ More specifically, this assumes a combination of i) a consumption tax hike by 10 percentage points cumulatively ( 3 percentage points each in 2011 and 2013, and 2 percentage points each in 2015 and 2017); and ii) a corporate tax cut by 0.5 percent of GDP in 2011.
} 
Under this scenario, the net debt GDP ratio would peak at 140 percent ( 240 percent of GDP in gross terms) in 2014 and then decline to below 100 percent by 2030 . Compared to other countries, the consolidation pace of about one percentage point per year can be considered ambitious, as international experience shows that few advanced economies have succeeded in maintaining an adjustment of 1 percent of GDP or higher annually over 10 years,

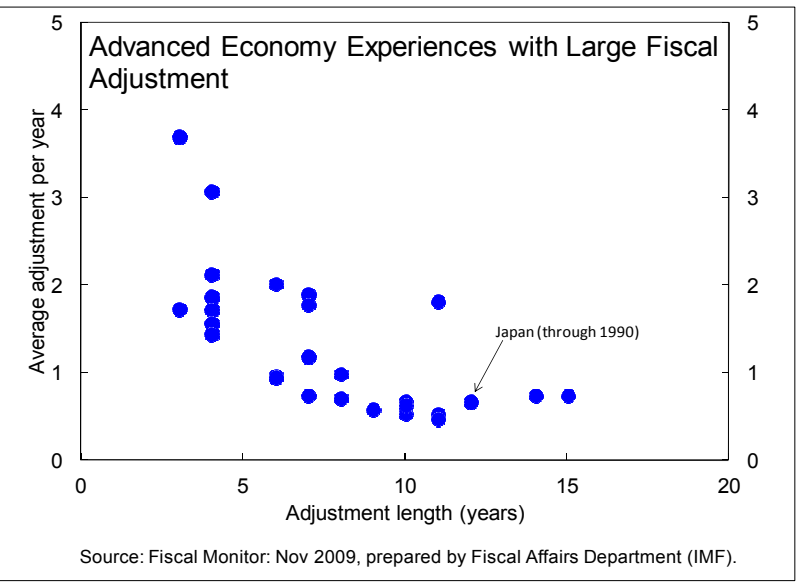
possibly reflecting reform fatigue.

Delayed and more gradual adjustment scenario. A further delay relative to the policy adjustment scenario would leave net public debt at unsustainably high levels (around 140 percent of GDP) long into the future. In this scenario, the start of the consumption hike is delayed by 3 years to 2014 relative to the policy adjustment scenario and the overall improvement of the structural primary balance between 2010 and 2020 is reduced to 8.5 percent of GDP (from 10 percent of GDP in the policy adjustment scenario).

Sensitivity analysis. The debt sustainability results are sensitive to macroeconomic assumptions. In particular, a higher interest rate growth differential (than the baseline of $1 \frac{1 / 4}{4}$ percent) would lead to an even faster pace of debt accumulation. For example, in the policy adjustment scenario, assuming an interest rate growth differential of 4 percent would fail to stabilize the public debt ratio, while a modestly higher differential of 2 percent would still bring down the debt ratio but to a higher level. Returning to the public debt ratio to its pre-crisis level by 2030 would require an adjustment of 12-15 percent of GDP.

\begin{tabular}{|c|c|c|c|c|c|c|}
\hline \multicolumn{7}{|c|}{ Net Public Debt (in percent of GDP) } \\
\hline & \multirow[b]{2}{*}{$\begin{array}{c}\text { Nominal } \\
\text { Interest Rate } \\
\text { Growth Differential } \\
\text { over the Long } \\
\text { Term } \\
\text { (in percent) }\end{array}$} & \multirow[b]{2}{*}{$\begin{array}{l}\text { Structural Primary } \\
\text { Balance } \\
\text { Improvement } \\
2010-2020\end{array}$} & \multicolumn{4}{|c|}{ Net Debt } \\
\hline & & & 2010 & 2015 & 2020 & 2030 \\
\hline \multirow[t]{3}{*}{ No adjustment scenario } & 1.25 (baseline) & 2.5 & 121 & 154 & 179 & 241 \\
\hline & 2.0 & 2.5 & 121 & 154 & 183 & 262 \\
\hline & 4.0 & 2.5 & 121 & 154 & 193 & 327 \\
\hline \multirow[t]{3}{*}{ Policy adjustment scenario } & 1.25 (baseline) & 10.0 & 121 & 136 & 124 & 99 \\
\hline & 2.0 & 10.0 & 121 & 136 & 127 & 112 \\
\hline & 4.0 & 10.0 & 121 & 136 & 135 & 152 \\
\hline \multirow[t]{3}{*}{ Target pre-crisis (2007) level in 2030} & 1.25 (baseline) & 12.4 & 121 & 144 & 130 & 81 \\
\hline & 2.0 & 13.1 & 121 & 143 & 129 & 81 \\
\hline & 4.0 & 14.9 & 121 & 140 & 127 & 81 \\
\hline
\end{tabular}


Table Japan: Public Sector Debt Sustainability Framework, 2007-2015

No Adjustment Scenario

(In percent of GDP, unless otherwise indicated)

\begin{tabular}{|c|c|c|c|c|c|c|c|c|c|}
\hline & 2007 & 2008 & 2009 & 2010 & 2011 & 2012 & 2013 & 2014 & 2015 \\
\hline 1 Public sector net debt $1 /$ & 81.5 & 94.9 & 111.6 & 121.4 & 130.3 & 137.2 & 143.5 & 148.9 & 154.3 \\
\hline 2 Change in public sector debt & -2.8 & 13.4 & 16.8 & 9.8 & 8.9 & 6.9 & 6.3 & 5.4 & 5.4 \\
\hline 3 Identified debt-creating flows $(4+7+12)$ & 1.1 & 5.8 & 16.5 & 9.5 & 8.7 & 6.4 & 5.7 & 4.7 & 4.1 \\
\hline 4 Primary deficit & 1.8 & 3.2 & 9.1 & 8.3 & 7.6 & 6.8 & 6.0 & 5.2 & 5.0 \\
\hline Revenue and grants & 31.0 & 31.5 & 29.5 & 29.8 & 30.3 & 30.8 & 31.5 & 32.0 & 32.0 \\
\hline 6 Primary (noninterest) expenditure & 32.8 & 34.8 & 38.6 & 38.1 & 37.9 & 37.6 & 37.5 & 37.3 & 37.0 \\
\hline 7 Automatic debt dynamics $2 /$ & -0.7 & 2.5 & 7.4 & 1.1 & 1.1 & -0.4 & -0.3 & -0.6 & -0.9 \\
\hline Contribution from interest rate/growth differential 3/ & -0.7 & 2.5 & 7.4 & 1.1 & 1.1 & -0.4 & -0.3 & -0.6 & -0.9 \\
\hline Of which contribution from real interest rate & 1.3 & 1.5 & 2.1 & 3.8 & 3.2 & 2.3 & 2.2 & 2.0 & 1.6 \\
\hline Of which contribution from real GDP growth & -1.9 & 1.0 & 5.3 & -2.7 & -2.1 & -2.6 & -2.5 & -2.5 & -2.4 \\
\hline Contribution from exchange rate depreciation $4 /$ & 0.0 & 0.0 & 0.0 & 0.0 & 0.0 & 0.0 & 0.0 & 0.0 & 0.0 \\
\hline Other identified debt-creating flows & 0.0 & 0.0 & 0.0 & 0.0 & 0.0 & 0.0 & 0.0 & 0.0 & 0.0 \\
\hline Privatization receipts (negative) & 0.0 & 0.0 & 0.0 & 0.0 & 0.0 & 0.0 & 0.0 & 0.0 & 0.0 \\
\hline Recognition of implicit or contingent liabilities & 0.0 & 0.0 & 0.0 & 0.0 & 0.0 & 0.0 & 0.0 & 0.0 & 0.0 \\
\hline Other (specify, e.g. bank recapitalization) & 0.0 & 0.0 & 0.0 & 0.0 & 0.0 & 0.0 & 0.0 & 0.0 & 0.0 \\
\hline 6 Residual, including asset changes (2-3) & -3.9 & 7.6 & 0.3 & 0.3 & 0.2 & 0.5 & 0.6 & 0.7 & 1.3 \\
\hline Public sector debt-to-revenue ratio (in percent) 1/ & 262.8 & 301.1 & 378.4 & 407.7 & 429.4 & 445.9 & 455.2 & 465.3 & 482.1 \\
\hline \multicolumn{10}{|l|}{ Key Macroeconomic and Fiscal Assumptions } \\
\hline Real GDP growth (in percent) & 2.3 & -1.2 & -5.2 & 2.4 & 1.8 & 2.0 & 1.9 & 1.8 & 1.7 \\
\hline Average nominal interest rate on public debt (in percent) $5 /$ & 0.8 & 1.1 & 1.2 & 1.3 & 1.4 & 1.4 & 1.5 & 1.6 & 1.6 \\
\hline Inflation rate (GDP deflator, in percent) & -0.7 & -0.8 & -0.9 & -2.1 & -1.3 & -0.4 & -0.1 & 0.2 & 0.5 \\
\hline
\end{tabular}

1/ General government basis.

2/ Derived as $[(r-p(1+g)-g+a e(1+r)] /(1+g+p+g p))$ times previous period debt ratio, with $r=$ interest rate; $p=$ growth rate of GDP deflator; $g=$ real GDP growth rate;

$\mathrm{a}=$ share of foreign-currency denominated debt; and $\mathrm{e}=$ nominal exchange rate depreciation (measured by increase in local currency value of U.S. dollar).

$3 /$ The real interest rate contribution is derived from the denominator in footnote $2 /$ as $r-\pi(1+g)$ and the real growth contribution as $-g$.

$4 /$ The exchange rate contribution is derived from the numerator in footnote $2 /$ as ae $(1+r)$.

$5 /$ Derived as nominal interest expenditure divided by previous period debt stock. 
INTERNATIONAL MONETARY FUND

JAPAN

Staff Report for the 2010 Article IV Consultation

Supplementary Information

Prepared by the Asia and Pacific Department

Approved by James Gordon and Tamim Bayoumi

June 25, 2010

The following information has become available since the preparation of the staff report. This information does not alter the thrust of the staff appraisal.

The cabinet led by new Prime Minister Naoto Kan endorsed a New Growth Strategy on June 18, 2010 and a Fiscal Management Strategy on June 22, 2010.

The New Growth Strategy, which builds on an earlier outline from December 2009, targets a nominal GDP growth rate of 3 percent ( 2 percent in real terms) over the next decade. It also aims to bring the unemployment rate below 4 percent from the current 5 percent range.

Measures. The strategy identifies seven key areas for development including the environment and energy, healthcare, growth of the Asian economy, tourism and local revitalization, science and technology, employment, and finance (see Box). Noteworthy measures include efforts to increase Japan's infrastructure industries overseas (such as high speed rail), a phased-in reduction of corporate taxes from 40 percent towards the level of other major advanced economies, and increased childcare services to strengthen female labor force participation.

Staff views: The new growth strategy contains a number of elements that could help raise potential growth. Measures aimed at boosting exports of infrastructure industries and reductions in corporate taxes could raise domestic investment and help Japan capture a larger share of the growing demand in the region. Other reforms to improve health care, increase labor participation, and strengthen education could expand labor supply and raise productivity. The staff report suggests some additional supply side measures focused on increasing employment, deregulating services, and encouraging more risk-based lending by private financial institutions that would complement efforts to raise trend growth.

The Fiscal Management Strategy outlines the government's fiscal plan for the coming decade to restore confidence in public finances and support sustained growth: 
- Short term: the government will make "utmost efforts" to cap the issuance of new Japanese government bonds (JGBs) in FY2011 (begins April 2011) at the FY2010 level ( $¥ 44$ trillion). There is also a commitment that central government primary spending (General Account excluding debt and interest payment) will not exceed the FY2010 level over the next three years.

- $\quad$ Medium- to long-term: the government commits to halving the government primary deficit in percent of GDP by FY2015 and achieving a primary surplus by FY2020 at the latest (central and local governments). It aims to stabilize the debt-to-GDP ratio around FY2020 targeting a steady decline of the debt ratio from FY2021 on. To help achieve this goal the government plans to introduce a "pay-as you-go" rule requiring that any new expenditure be funded by permanent reductions in expenditures or by additional revenue-raising measures.

- Measures. The strategy does not identify the composition or timing of possible revenue measures, but the government has called for a swift bipartisan discussion on the details of a comprehensive tax reform package, including changes to the consumption, income, and corporate taxes. The Prime Minister also mentioned the need to address equity concerns arising from a potential future increase of the consumption tax, for example, through reducing the rate on some products. On the expenditure side, the strategy is explicit about the need for medium-term spending caps, but does not discuss specific entitlement reforms that may be necessary.

- $\quad$ The government also issued a Medium-term Provisional Economic Fiscal Calculation to illustrate the size of the adjustment required. Under "conservative" macroeconomic assumptions" the authorities estimate that the primary balance budget in FY2020 would fall $¥ 21.7$ trillion (or 4 percent of GDP) short of the targeted primary balance without new revenue measures.

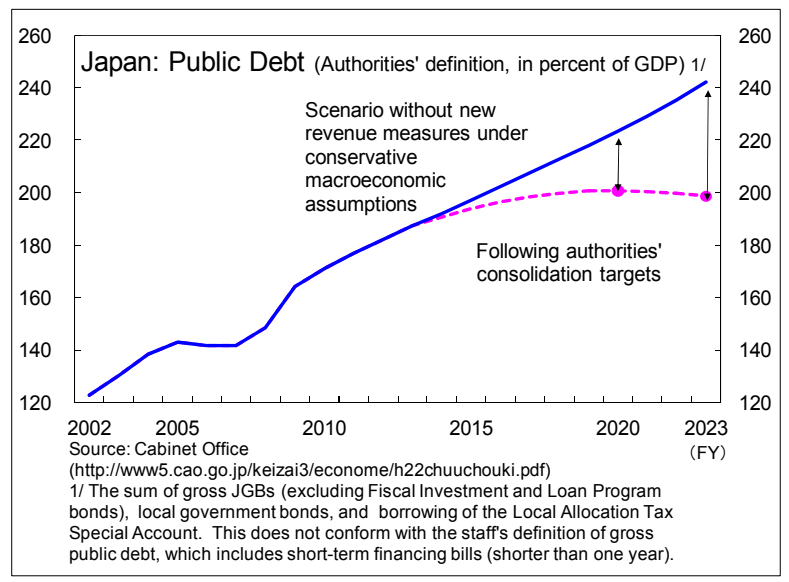

Staff views: Staff welcomes the fiscal adjustment strategy as an important step forward to laying out a medium-term adjustment path. The adjustment path envisaged is more gradual than under the staff's policy adjustment scenario and stabilizes the debt-ratio at a later date (FY2020 versus FY2015) and at a higher level. This leaves the fiscal position more vulnerable to potential adverse shocks for a prolonged time. Moreover, the strategy lacks specifics on new revenue measures to achieve this adjustment and in staff's view will only

\footnotetext{
${ }^{1}$ Real GDP growth is projected to converge to 1.2 percent in 2020.
} 
become fully credible once details of the necessary revenue measures are agreed on including the timing and scale of a consumption tax increase. Staff also welcomes the intention to adopt a pay-as-you go rule, which will enhance fiscal discipline, but still sees a need for a cap on public debt to anchor expectations.

\section{Box: Key Policy Areas of Japan's New Growth Strategy}

Environment and energy. Reduce dependence on fossil fuels and expand Japan's technology leadership by providing incentives to increase the supply and use of renewable energy and revitalize forestry.

Health care. Address demand pressures from population aging by promoting advanced medical services through deregulation and developing international medical business (medical tourism) through more flexible visa issuances.

Growth of Asian economy. Expand overseas operations of infrastructure industries by taking advantage of Japan's leadership in transportation and communication technology and through support from public financial institutions (e.g., Japan Bank for International Cooperation). Attract foreign companies to Japan by cutting the effective corporate tax rate, developing global human resources, accepting more foreign skilled labor, and promoting economic partnerships, including through a Free Trade Area of the Asia-Pacific (FTAAP).

Tourism and local revitalization. Encourage tourism by developing special tourism areas, and expediting issuance of tourist visas. In parallel expand markets for existing housing and home renovation, and strengthen public services by opening management to the private sector.

Science and technology. Foster innovation and growth and enhance international competitiveness through higher public and private $R \& D$ spending, better human resource development including through university reforms, and improved communication technology.

Employment. Strengthen female labor force participation by improving child care services and adopting more flexible work arrangements.

Finance. Develop the financial sector by promoting the establishment of an integrated exchange for securities, other financial instruments, and commodities. 


\section{INTERNATIONAL MONETARY FUND}

\section{JAPAN}

\section{Staff Report for the 2010 Article IV Consultation-Informational Annex}

Prepared by the Asia and Pacific Department

(In consultation with other departments)

June 17,2010

Contents

Page

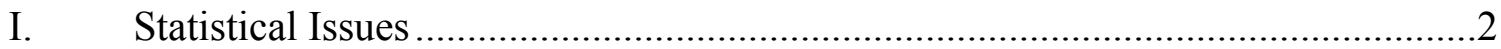

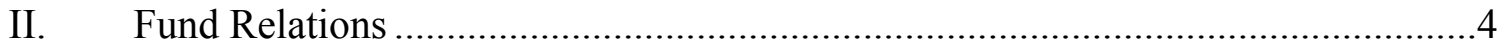




\section{ANNEX I. JAPAN-STATISTICAL ISSUES}

Statistical Issues: Economic and financial data provided to the Fund are considered adequate for surveillance purposes. Japan subscribes to the Special Data Dissemination Standard (SDDS) and meets the SDDS specifications for the coverage, periodicity, and timeliness of data. The Japanese authorities hosted a data module mission for a Report on the Observance of Standards and Codes (data ROSC) in September 12-28, 2005. The Report on Observance of Standards and Codes - Data Module, Response by the Authorities, and Detailed Assessments Using the Data Quality Assessment Framework (DQAF) were published March 17, 2006 and are available at

http://www.imf.org/external/pubs/ft/scr/2006/cr06115.pdf 
Japan: Table of Common Indicators Required for Surveillance (as of June 8, 2010)

\begin{tabular}{|c|c|c|c|c|c|c|c|}
\hline & \multirow{2}{*}{$\begin{array}{c}\text { Date of } \\
\text { Latest } \\
\text { Observation }\end{array}$} & \multirow{2}{*}{$\begin{array}{c}\text { Date } \\
\text { Received }\end{array}$} & \multirow{2}{*}{$\begin{array}{c}\text { Frequency } \\
\text { of } \\
\text { Data }^{6}\end{array}$} & \multirow{2}{*}{$\begin{array}{c}\text { Frequency } \\
\text { of } \\
\text { Reporting }^{6}\end{array}$} & \multirow{2}{*}{$\begin{array}{l}\text { Frequency of } \\
\text { Publication }^{6}\end{array}$} & \multicolumn{2}{|c|}{ Memo Items: } \\
\hline & & & & & & $\begin{array}{l}\text { Data Quality - } \\
\text { Methodological } \\
\text { soundness }\end{array}$ & $\begin{array}{l}\text { Data Quality - } \\
\text { Accuracy and } \\
\text { reliability }^{8}\end{array}$ \\
\hline Exchange Rates & June 2010 & June 2010 & $\mathrm{D}$ & $\mathrm{D}$ & $\mathrm{D}$ & & \\
\hline $\begin{array}{l}\text { International Reserve Assets and Reserve Liabilities of the } \\
\text { Monetary Authorities }{ }^{1}\end{array}$ & May 2010 & June 2010 & M & M & M & & \\
\hline Reserve/Base Money & May 2010 & June 2010 & M & M & M & \multirow{4}{*}{ LO, LO, LO, LO } & \multirow{4}{*}{$\mathrm{O}, \mathrm{O}, \mathrm{O}, \mathrm{O}, \mathrm{O}$} \\
\hline Broad Money & May 2010 & June 2010 & M & M & M & & \\
\hline Central Bank Balance Sheet & $5 / 31 / 10$ & $6 / 2 / 10$ & $\begin{array}{r}\text { Every } 10 \\
\text { days }\end{array}$ & $\begin{array}{r}\text { Every } 10 \\
\text { days }\end{array}$ & $\begin{array}{r}\text { Every } 10 \\
\text { days }\end{array}$ & & \\
\hline Consolidated Balance Sheet of the Banking System & Apr 2010 & June 2010 & M & M & M & & \\
\hline Interest Rates ${ }^{2}$ & June 2010 & June 2010 & $\mathrm{D}$ & $\mathrm{D}$ & $\mathrm{D}$ & & \\
\hline Consumer Price Index & May 2010 & May 2010 & M & M & M & O, LO, O, O & $\mathrm{O}, \mathrm{O}, \mathrm{LO}, \mathrm{O}, \mathrm{O}$ \\
\hline $\begin{array}{l}\text { Revenue, Expenditure, Balance and Composition of } \\
\text { Financing }^{3}-\text { General Government }{ }^{4}\end{array}$ & 2008 & Feb 2010 & A & A & A & \multirow{2}{*}{$\mathrm{O}, \mathrm{LNO}, \mathrm{O}, \mathrm{O}$} & \multirow{2}{*}{$\mathrm{LO}, \mathrm{O}, \mathrm{O}, \mathrm{O}, \mathrm{LO}$} \\
\hline $\begin{array}{l}\text { Revenue, Expenditure, Balance and Composition of } \\
\text { Financing }{ }^{3} \text { - Central Government }\end{array}$ & 2008 & Feb 2010 & A & A & A & & \\
\hline $\begin{array}{l}\text { Stocks of Central Government and Central Government- } \\
\text { Guaranteed Debt }\end{array}$ & Mar 2010 & May 2010 & Q & Q & Q & & \\
\hline External Current Account Balance & Apr 2010 & June 2010 & M & M & M & \multirow[b]{2}{*}{ O, O, LO, O } & \multirow[b]{2}{*}{$\mathrm{LO}, \mathrm{O}, \mathrm{O}, \mathrm{O}, \mathrm{O}$} \\
\hline Exports and Imports of Goods and Services & Apr 2010 & June 2010 & $\mathrm{M}$ & $\mathrm{M}$ & $\mathrm{M}$ & & \\
\hline GDP/GNP & 2010 Q1 & May 2010 & Q & Q & Q & $\mathrm{O}, \mathrm{O}, \mathrm{O}, \mathrm{O}$ & $\begin{array}{l}\text { LO, LO, O, O, } \\
\text { LNO }\end{array}$ \\
\hline Gross External Debt & Mar 2010 & June 2010 & $Q$ & $Q$ & $Q$ & & \\
\hline
\end{tabular}

${ }^{1}$ Includes reserve assets pledged or otherwise encumbered as well as net derivative positions.

${ }^{2}$ Both market-based and officially-determined, including discount rates, money market rates, rates on treasury bills, notes and bonds.

${ }^{3}$ Foreign, domestic bank, and domestic nonbank financing.

${ }^{4}$ The general government consists of the central government (budgetary funds, extra budgetary funds, and social security funds) and state and local governments.

${ }^{5}$ Including currency and maturity composition.

${ }^{6}$ Daily (D); weekly (W); monthly (M); quarterly (Q); annually (A); irregular (I); and not available (NA).

${ }^{7}$ Reflects the assessment provided in the data ROSC or the Substantive Update (published on May 17, 2006, and based on the findings of the mission that took place during

September 2005) for the dataset corresponding to the variable in each row. The assessment indicates whether international standards concerning concepts and definitions, scope,

classification/sectorization, and basis for recording are fully observed (O); largely observed (LO); largely not observed (LNO); not observed (NO); and not available (NA).

${ }^{8}$ Same as footnote 7, except referring to international standards concerning (respectively) source data and its assessment, statistical techniques, assessment and validation of intermediate data and statistical outputs, and revision studies. 


\section{ANNEX II. JAPAN-Fund RELATIONS}

(As of May 31, 2010)

I. Membership Status: Joined 8/13/52; Article VIII

II. General Resources Account:

SDR Million

Quota

$13,312.80$

\% Quota

Fund holdings of currency

$10,717.06$

100.00

Reserve position in Fund

$2,596.59$

80.50

19.50

III. SDR Department:

$\begin{array}{cc}\text { SDR Million } & \text { \% Allocation } \\ 12,284.97 & 100.00 \\ 13,381.54 & 108.93\end{array}$

IV. Outstanding Purchases and Loans: None

V. Latest Financial Arrangements: None

VI. Projected Obligations to Fund: None

\section{Exchange Rate Arrangement:}

Japan maintains a floating exchange rate regime. The exchange system is free of restrictions on the making of payments and transfers for current international transactions, with the exceptions of restrictions maintained against the Taliban, Al-Qaeda, the former Iraqi regime, and others, pursuant to UN Security Council Resolutions 1267, 1333, 1390, 1373, 1483, and 1532 .

\section{Article IV Consultation:}

The 2009 Article IV consultation discussions were held during May 12-20, 2009; the Executive Board discussed the Staff Report (IMF Country Report No. 09/210 and concluded the consultation on July 17, 2009. The concluding statement, staff report, staff supplement, selected issues paper, and PIN were all published. 
Public Information Notice (PIN) No. 10/87 FOR IMMEDIATE RELEASE July 14,2010
International Monetary Fund

$70019^{\text {th }}$ Street, NW

Washington, D. C. 20431 USA

\section{IMF Executive Board Concludes 2010 Article IV Consultation with Japan}

On July 2, 2010, the Executive Board of the International Monetary Fund (IMF) concluded the Article IV consultation with Japan. ${ }^{1}$

\section{Background}

Japan's economy continues to improve led by robust exports and policy stimulus. Following a deep recession in 2009, growth accelerated to 5 percent (seasonally adjusted annual rate) in the first quarter of 2010 amid signs of exports spilling over to domestic demand. Strong demand from Asia, especially for capital goods, has supported exports, while subsidies aimed at consumer durables has lifted household spending. With the sharp fall in demand last year, deflation has re-emerged with core inflation averaging around -1 percent since late 2009.

The current account surplus shrank further in 2009 to 2.8 percent of GDP, as a result of lower global interest rates and a stronger yen. The trade surplus remained unchanged at around 1 percent of GDP, while the income balance deteriorated in line with lower global interest rates.

Financial markets have been hit hard by the renewed global turmoil. After showing signs of recovering through March 2010, equity prices have fallen and the yen again appreciated on higher risk aversion. Since the Lehman shock, the yen has appreciated by 16 percent in real effective terms, while ten-year Japanese government bond (JGB) yields have been stable at around 1.2-1.4 percent.

\footnotetext{
${ }^{1}$ Under Article IV of the IMF's Articles of Agreement, the IMF holds bilateral discussions with members, usually every year. A staff team visits the country, collects economic and financial information, and discusses with officials the country's economic developments and policies. On return to headquarters, the staff prepares a report, which forms the basis for discussion by the Executive Board. At the conclusion of the discussion, the Managing Director, as Chairman of the Board, summarizes the views of Executive Directors, and this summary is transmitted to the country's authorities. An explanation of any qualifiers used in summings up can be found here:

http://www.imf.org/external/np/sec/misc/qualifiers.htm.
} 
Looking forward, the recovery is expected to continue but its pace will likely moderate. GDP growth is projected to rise to 2.4 percent in 2010 with the pace of the recovery likely to slow in the second half of the year as stimulus measures expire and export growth levels off. Growth of 1.8 percent is expected in 2011. With a narrowing of the output gap, headline inflation is projected to turn positive in late 2011. Considerable uncertainty surrounds the outlook from the global market turmoil, a possible slowdown in the advanced economies and China, and a potential worsening of deflation.

With global scrutiny of public finances on the rise, the need for early and credible fiscal adjustment has increased. The severe recession and the fiscal response have pushed the overall fiscal deficit to $101 / 4$ percent of GDP in 2009 and the net public debt ratio to 110 percent of GDP, one of the highest among advanced economies.

To combat the recession and re-emergence of deflation, the Bank of Japan (BoJ) adopted a number of additional measures over the past year. These include introducing a 3-month funds supplying operation to lower short-term interest rates, re-activating its U.S. dollar swap line to ease emerging funding pressures, and introducing a new loan facility to support private bank lending to innovative firms.

\section{Executive Board Assessment}

Japan's economy is gaining strength, helped by strong external demand and timely and sizeable policy support. With domestic demand gradually improving and deflation easing, the recovery is expected to continue-albeit at a more moderate pace. The recent turmoil in Europe, however, has heightened risks to the outlook and Japan's vulnerability to sovereign risk.

Against this backdrop, Directors underscored the urgency of credible fiscal adjustment. The key challenge is to bring down public debt to more sustainable levels—through decisive and sustained fiscal action-while ensuring adequate support for the still nascent recovery and a more balanced economy. Directors welcomed the Fiscal Management Strategy recently announced, laying out a medium-term consolidation path, and looked forward to agreement on specific measures. They generally agreed that adjustment efforts should focus on a gradual increase in the consumption tax, supported by comprehensive tax reform, limits on non-social security spending growth, and reforms to entitlement programs. The pace, timing, and composition of consolidation measures would need to be carefully planned, with special attention to their impact on consumption, investment, and growth. Directors commended the government for its plan to adopt a "pay-as-you-go" expenditure rule. Introducing a cap on public debt would help strengthen the credibility of the fiscal consolidation plans.

Directors considered the accommodative monetary policy stance appropriate, and welcomed various measures by the BoJ to combat deflation and support growth. They encouraged the authorities to stand ready to take additional easing measures, if deemed necessary in response to weakening recovery or renewed deflationary pressures. In this regard, consideration could be given to extending the maturity of the funds supplying operations and broadening the range of asset purchases, while being attentive to moral hazard risks. Directors stressed that, given growing uncertainty, clear 
communication would be crucial, with a few recommending that the BoJ more explicitly link its intention to maintain policy accommodation to its inflation forecast, provided that financial imbalances remain absent.

Directors welcomed the authorities' continued commitment to a market-determined exchange rate, which would help facilitate a rebalancing of growth away from exports. They noted the staff's assessment that, following the sharp appreciation since the outbreak of the crisis, the yen's current level is broadly in line with its longer-term equilibrium value. Nevertheless, carry trade activities and their impact on the exchange rate would need to be monitored closely.

Directors noted that, while the profitability and capital base of the banking sector have improved, banks still face risks from a slow recovery and their sizeable securities holdings, as well as challenges in adapting to new global financial standards. It would therefore be important for supervisors to ensure that banks follow proper risk management; take appropriate steps to facilitate borrower restructuring; and stand ready, when necessary, to assist banks in strengthening their financial positions.

Directors emphasized that the unprecedented size of required fiscal consolidation, including to address the challenges of population aging, brings to the fore the need for structural reforms to promote domestic demand-led growth. The formulation of the "New Growth Strategy" is a welcome step, entailing the development of potentially dynamic areas, such as energy, environment, health, and technology. This could be complemented by supply-side measures aimed at increasing employment, raising productivity in nontradable sectors, deregulating services, and encouraging more riskbased lending by private financial institutions.

Public Information Notices (PINs) form part of the IMF's efforts to promote transparency of the IMF's views and analysis of economic developments and policies. With the consent of the country (or countries) concerned, PINs are issued after Executive Board discussions of Article IV consultations with member countries, of its surveillance of developments at the regional level, of post-program monitoring, and of ex post assessments of member countries with longer-term program engagements. PINs are also issued after Executive Board discussions of general policy matters, unless otherwise decided by the Executive Board in a particular case. The staff report (use the free Adobe Acrobat Reader to view this pdf file) for the 2010 Article IV Consultation with Japan is also available. 
Japan: Selected Economic Indicators

\begin{tabular}{|c|c|c|c|c|c|c|}
\hline & 2006 & 2007 & 2008 & 2009 & $\begin{array}{l}\text { Proj. } \\
2010\end{array}$ & \\
\hline Real GDP & 2.0 & 2.4 & -1.2 & -5.2 & 2.4 & \\
\hline Private consumption & 1.5 & 1.6 & -0.7 & -1.0 & 1.5 & \\
\hline Nonresidential investment & 2.3 & 2.6 & 0.1 & -19.3 & 1.2 & \\
\hline Residential investment & 0.5 & -9.6 & -8.1 & -14.2 & -7.4 & \\
\hline Public investment & -5.7 & -7.4 & -8.5 & 7.4 & -5.4 & \\
\hline Government consumption & 0.4 & 1.5 & 0.3 & 1.5 & 1.2 & \\
\hline Stockbuilding (contribution to growth) & 0.2 & 0.3 & -0.4 & -0.4 & 0.1 & \\
\hline Net exports (contribution to growth) & 0.8 & 1.1 & 0.1 & -1.3 & 1.8 & \\
\hline Exports of goods and services & 9.7 & 8.4 & 1.6 & -23.9 & 19.5 & \\
\hline Imports of goods and services & 4.2 & 1.6 & 1.0 & -16.7 & 7.5 & \\
\hline \multicolumn{7}{|l|}{ Inflation (period average) } \\
\hline GDP deflator & -0.9 & -0.7 & -0.8 & -0.9 & -2.1 & \\
\hline $\mathrm{CPI}(\mathrm{SA})$ & 0.3 & 0.1 & 1.4 & -1.4 & -1.2 & \\
\hline CPI (NSA) & 0.2 & 0.1 & 1.4 & -1.4 & -1.2 & \\
\hline Unemployment rate (period average) & 4.1 & 3.9 & 4.0 & 5.1 & 4.9 & \\
\hline \multicolumn{7}{|l|}{ Current account balance } \\
\hline Billions of U.S. dollars & 170.4 & 211.0 & 157.1 & 141.8 & 162.9 & \\
\hline Percent of GDP & 3.9 & 4.8 & 3.2 & 2.8 & 3.1 & \\
\hline \multicolumn{7}{|c|}{ General government balances (percent of GDP) } \\
\hline Overall balance & -4.0 & -2.4 & -4.1 & -10.3 & -9.8 & \\
\hline Primary Balance & -3.4 & -1.8 & -3.2 & -9.1 & -8.3 & \\
\hline Structural primary balance & -3.2 & -1.9 & -2.7 & -6.2 & -6.2 & \\
\hline \multicolumn{7}{|c|}{$\begin{array}{l}\text { Money and credit (12-month growth rate, end- } \\
\text { period) }\end{array}$} \\
\hline Base money & -20.0 & 0.4 & 1.8 & 5.2 & 3.7 & 1/ \\
\hline M2 (period average) & 0.7 & 2.1 & 1.8 & 3.1 & 3.1 & $1 /$ \\
\hline Bank lending ${ }^{2 /}$ & 2.8 & 0.8 & 4.6 & -0.9 & -1.9 & $1 /$ \\
\hline \multicolumn{7}{|c|}{ Exchange and interest rates (period average) } \\
\hline Yen/dollar rate & 116.3 & 117.8 & 103.4 & 93.6 & 88.3 & $3 /$ \\
\hline Yen/euro rate & 146.0 & 161.4 & 152.1 & 130.3 & 108.9 & $3 /$ \\
\hline Real effective exchange rate & 64.1 & 59.3 & 65.6 & 71.3 & 72.0 & $1 /$ \\
\hline 3-month CD rate & 0.2 & 0.5 & 0.5 & 0.3 & 0.3 & 31 \\
\hline
\end{tabular}

Sources: Global Insight, Nomura database, and IMF staff estimates and projections.

1/ May 2010.

2/ Data reflect the inclusion of foreign banks, foreign trust banks and Shinkin banks in the monetary survey.

3/ July 1, 2010. 